\title{
Terracotta Pipelines at Maloutena Remarks on the Water System in the Residential District of Ancient Nea Paphos, Cyprus
}

\author{
MARCIN M. ROMANIUK
}

\begin{abstract}
This paper presents the results of studies on the ancient terracotta pipelines discovered during excavations conducted since 1965 by the Polish Archaeological Mission of the University of Warsaw in the so-called Maloutena area, the residential district of the Hellenistic-Roman capital of Cyprus, Nea Paphos. The pipelines were examined in terms of the pipe types they were composed of, their construction and maintenance aspects, chronology, function and structural interrelations to recognise the role they played in the water management system of Maloutena and Nea Paphos over time.
\end{abstract}

Keywords: terracotta pipelines, Nea Paphos, Hellenistic-Roman Cyprus, water tower

Marcin M. Romaniuk, Institute of Mediterranean and Oriental Cultures, Polish Academy of Sciences, Warsaw; mromaniuk@iksio.pan.pl; archeologpolski@wp.pl; (D) 0000-0002-7500-5960

Terracotta pipelines ${ }^{1}$ are a commonly encountered feature at Eastern Mediterranean GraecoRoman urban sites. Although often preserved fragmentarily, upon closer examination they may constitute a valuable source of knowledge on the ancient urban water systems. Addressing this assumption, the author undertook studies on the terracotta pipelines discovered during excavations conducted since 1965 by the Polish Archaeological Mission of the University of Warsaw ${ }^{2}$ in the residential district (the so-called Maloutena area) of the Hellenistic-Roman capital of Cyprus, Nea Paphos (Fig. 1).

The city was located on the south-western coast of Cyprus, at the small promontory constituting the maritime terrace of massively karstified carbonate rock basement. ${ }^{3}$ There are two small periodic rivers in its vicinity, Koskinas in the north and Limnaria in the

\footnotetext{
${ }^{1}$ To clarify, in this paper the term 'pipe' is used for single clay tube, while the term 'pipeline' is used for a line composed of the numerous joined pipes. Also, hereafter the shortcut 'PP' with the appropriate number will be used to describe particular pipelines.

2 The Mission, inaugurated in 1965 by Kazimierz Michałowski, was further led consecutively by Wiktor A. Daszewski (1971-2007), Henryk Meyza (2008-2019), and, currently, Ewdoksia Papuci-Władyka.

${ }^{3}$ Kalicki, Chwałek, Frączek 2020: 489.
} 


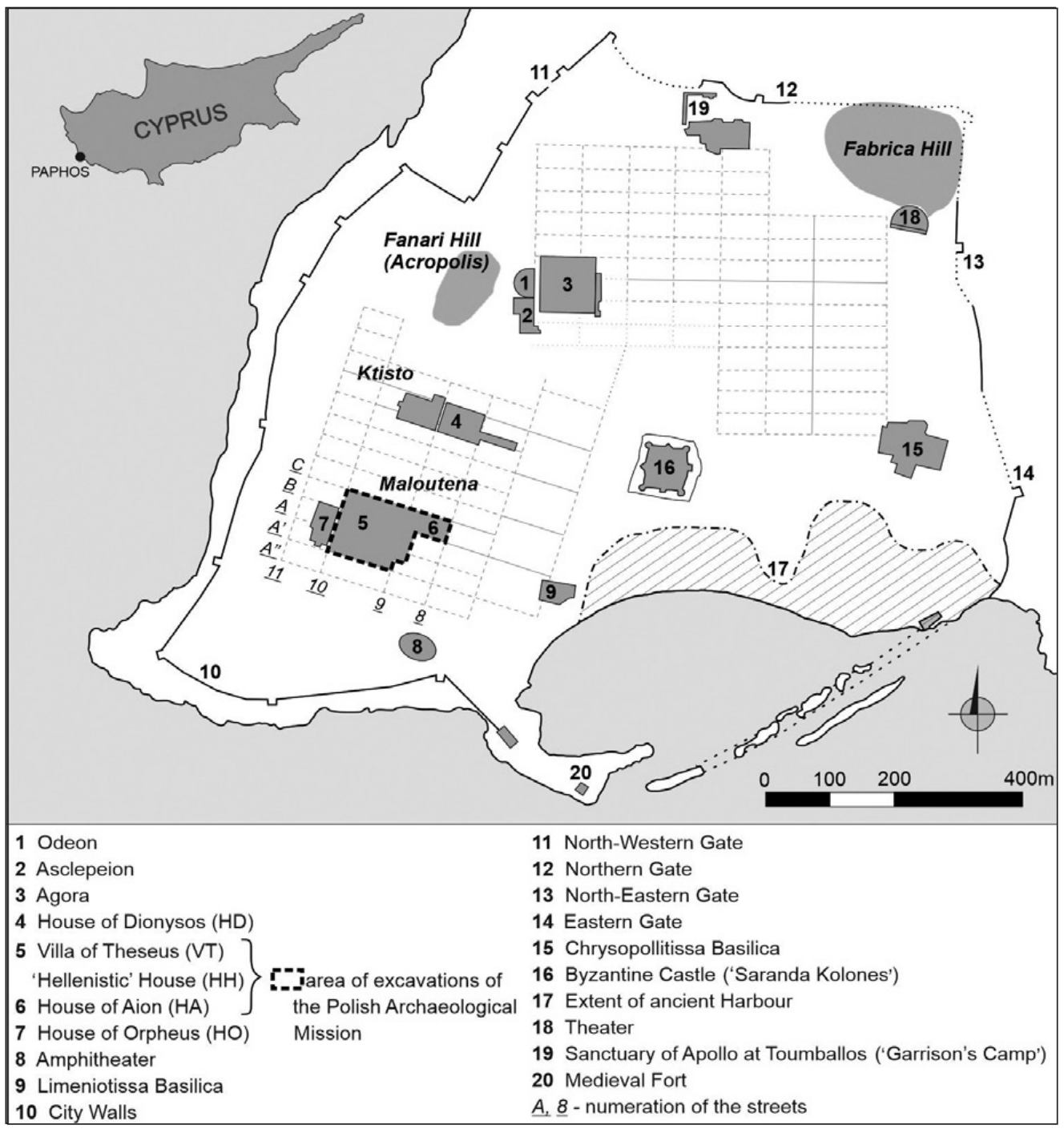

1. Plan of ancient Nea Paphos (Drawing: M.M. Romaniuk; based on: Papuci-Władyka 2020: Pl. 5).

east (and one larger river, Ezousa, further to the east). ${ }^{4}$ The local climate is semi-arid, ${ }^{5}$ characteristic of Eastern Mediterranean lands, with hot, dry summers and rainy winters

4 Jolanta Młynarczyk (Młynarczyk 1990: 91) notes about three streams to be located east of the city in antiquity. The largest and farthest to the east one can be identified most likely with the modern Limnaria stream. The second one, about 250m to the west, was just outside the hypothetical course of the eastern city wall. The last one had its mouth west of the eastern pier of the ancient port (therefore within the harbour bay). One of them was possibly mentioned in the tenth-century-AD literary source by Joannes Cameniata (Młynarczyk 1990: 31).

${ }^{5}$ Average rainfall in the south-west coastal area is $480 \mathrm{~mm}$ per year, while maximum average temperature up to $31^{\circ}$ in July and August, and 16-18 in January and February (Sparrow, John 2016: 9). 
causing, respectively, seasonal water shortage alternating with storm floods. Due to such hydrological conditions, the city needed an effective water supply and drainage system, of which the manifestation - apart from the other hydraulic installations - are the investigated pipelines. ${ }^{6}$

Founded in the late fourth century BC, over a century later Nea Paphos became the capital of Cyprus under the Ptolemies of Egypt, ${ }^{7}$ keeping this function after acquiring of the island by the Romans in 58 BC. The city was destroyed numerous times by earthquakes ${ }^{8}$ and rebuilt again until a devastating series of earthquakes in the fourth century AD, after which it never gained its earlier splendour. Until then it was one of the most important cities in the region, which was reflected in the erection of the assumed palace of the Roman governor, ${ }^{9}$ Villa of Theseus (hereafter as VT), ${ }^{10}$ in the south-western part of the city, in the Maloutena area.

Excavations by the Polish mission at the Maloutena site revealed relics of numerous wealthy houses (Fig. 2). ${ }^{11}$ In the Hellenistic and early Roman periods, the buildings - among them the so-called 'Hellenistic' House (hereafter $\mathrm{HH}$ ) built around the second/first century BC $^{12}$ and rebuilt repeatedly until destruction in the first half of the second century $\mathrm{AD}^{13}$ - were fit into insulae drawn by a regular grid of streets. ${ }^{14}$ In the late second century $\mathrm{AD}$, this layout was disturbed by the erecting of the VT, which cut Street A (E-W axis) and Street 9 (N-S axis). By its final development phase, dated to the fourth century AD, this building

${ }^{6}$ Hitherto, no more detailed studies devoted to the past hydrological conditions in the ancient Nea Paphos have been published. It can be said, however, that in the Hellenistic-Roman period the Levant went out through two major peaks of wetter (than today) climate, in which Cyprus was most likely included. The first peak is dated to around 150/100 BC to AD 200/250 (McCormick et al. 2012: 180, 183) and the second to various points between the fourth and fifth centuries AD (McCormick et al. 2012: 188, 197). Additionally, modern rainfall in Cyprus is decreasing successively, according to the statistics from the last decades of the last century (Hadjioannou 1997 cit. per Kambanellas 2012: 303), while intensive development of hydrotechnical infrastructure (drilling of boreholes, construction of retention reservoirs) during last over hundred years (especially since 1960) has resulted into a serious depletion of water in some areas (Kampanellas et al. 2003: 9-11, 14). From the above findings it can be concluded that the Nea Paphos area was better watered in the past than today, however, rather not as much as to force a change of the general, semi-arid character of the land. See also footnote 16 below.

7 Mitford 1980: 1309.

${ }^{8}$ For discussion on the ancient earthquakes that hit Nea Paphos, see: Młynarczyk 1990: 33-34.

${ }^{9}$ Daszewski 1977; Medeksza 1992. For references on the other interpretations of the building, see: Miszk 2020: 154, n. 69.

${ }^{10}$ Further, the number added to the abbreviation of the building name marks the number of the particular room or corridor, e.g. HH1 for the Room 1 (Main Courtyard) in HH.

11 For general overview of structures discovered at Maloutena, see: Młynarczyk 2016: 34-35.

12 Date based on the ceramic material (Daszewski 1994: 103), as well as the stylistic of the mosaic decoration (Daszewski 1991: 83) and of the corinthian capitel (Papageorghiou 1990: 977) found in HH10. These architectural features were incorporated into the later construction of the HH erected most likely after the earthquake of 17/15 вс (Młynarczyk 2016: 34).

${ }^{13}$ In the late second century AD the south-western part of $\mathrm{HH}$ was overbuilt by the so-called Roman House (further as RH; Daszewski 1995: 72).

${ }^{14}$ Excavations show that $\mathrm{HH}$ occupied only the west part of the insula marked by Streets 10, 9, A and A', while east part was occupied by the so-called Early Roman House (Daszewski 2016). For more information on the street layout of Nea Paphos, see: Młynarczyk 1985; 1990: 166-177. 


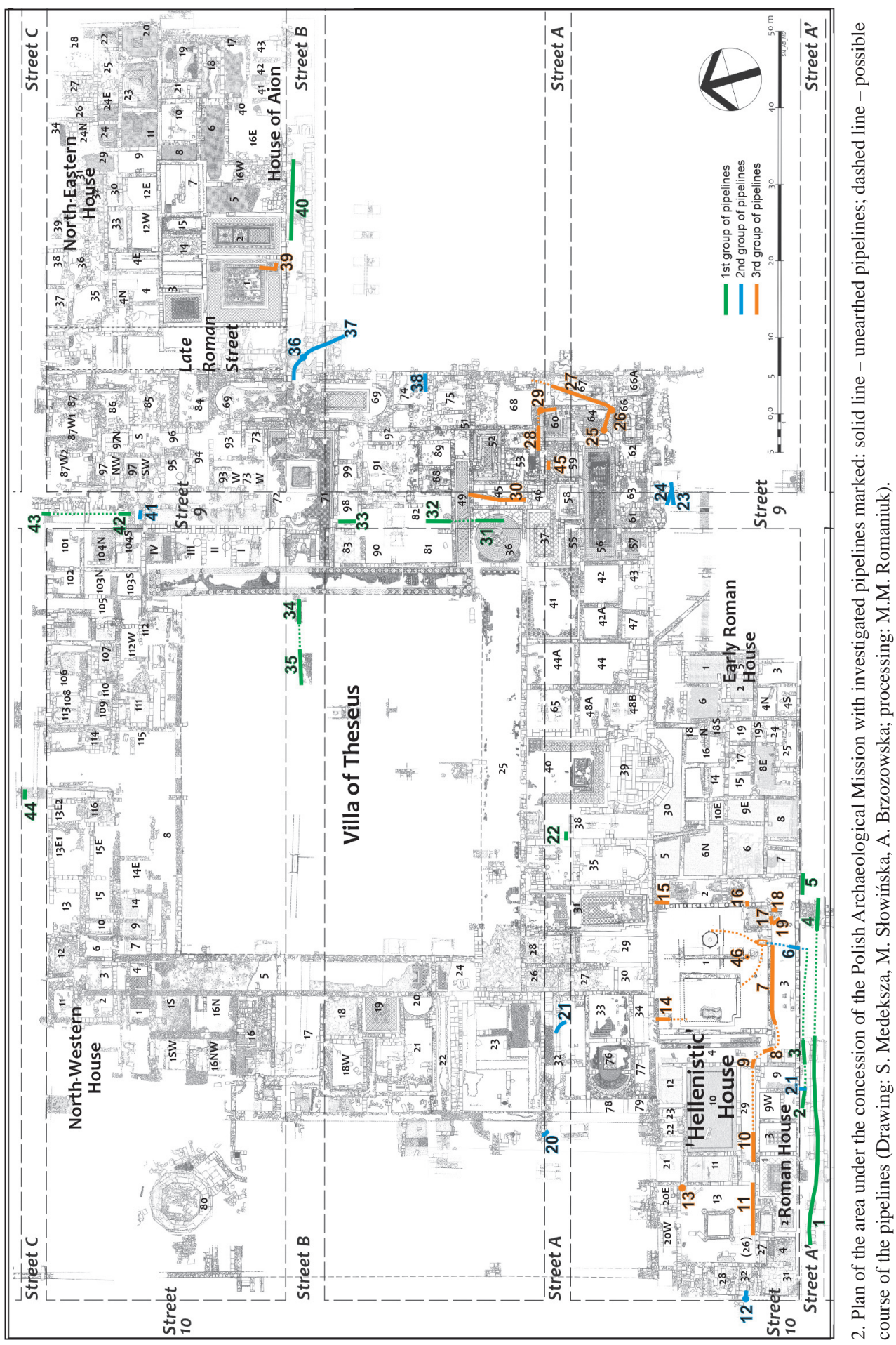


was extended to the north over an area of several insulae, as far as Street $\mathrm{C}$ (E-W axis), respecting, however, the general orientation of the layout. ${ }^{15}$ At that time new N-S axis route, called the Late Roman Street, was constructed along the east wall of the VT and another wealthy villa, the House of Aion (hereafter HA), was also erected east of it. Soon after the fourth-century earthquakes the area started to degrade, and by the sixth century had been occupied by squatters.

Within the excavated area numerous water-related devices were found, such as underground cisterns/wells, ${ }^{16}$ channels, under-street sewers, baths, ornamental pool, impluvium or nympheum. ${ }^{17}$ Among them were the terracotta pipelines, particularly important as they connected other elements of the water system, but which have to date not been examined systematically. This article attempts to fill this gap by analysing them in terms of the pipe types they were composed of, construction and maintenance aspects, chronology, possible function and structural interrelations, aiming to understand their role in the water system of Maloutena and Nea Paphos over time, and draw more general conclusions about the water supply and distribution within the city.

\section{METHODOLOGY AND LIMITATIONS OF RESEARCH}

The fragmentary preservation and limited field-accessibility of the pipelines at Maloutena preclude tracking their course from start to destination, and determining, thus, their exact role in the local water system. Since ancient written sources devoted to water architecture,

${ }^{15}$ For architectural description of VT, and the periodisation and characteristic of its building phases, see: Medeksza 1992; 1998.

${ }^{16}$ It can rarely be determined whether a discovered inlet belongs to an underground cistern or a well, especially as some cisterns had well-like narrow, stone-built shafts reaching even several meters down to the ground. To date, only one feature, located at the eastern wall of VT68, may be treated as a potential well due to the groundwater that appeared there at the level of $c .1 \mathrm{~m}$ asl $(7.25 \mathrm{~m}$ below the head level) during excavations. Its freshwater content still needs to be verified as Maloutena lies at the maritime terrace, and water table was observed close to the sea level, thus the water might have been contaminated by seawater. The geohydrological survey conducted in the Paphos region did not include the area of the Maloutena (Hadjistavrinou, Afrodisis 1977), preventing this issue to be resolved. It concludes, however, that the water from the region shows 'a high calcium carbonate content, low to medium sodium chlorite content and in some places a high sulphate content due to contamination from gypsum water' and ' $\mathrm{pH}$ factor ranges from 7.0-8.5, indicating neutral to alkaline water' (Hadjistavrinou, Afrodisis 1977: 21). The map of the Paphos area (Ktima 1955), preceding the major developments of hydrotechnical infrastructure of Cyprus after 1960 and environmental changes caused by them, shows no freshwater intakes in the area west of Saranda Kolones (Fig. 1, no. 16), which may support the above hypothesis about the salination of the water. Apart from this, alleged wells were located in the nearby House of Orpheus (further as HO), but were barely mentioned in reports (Christou 1992: 823). Thus far, the closest to Maloutena (Hadjistavrinou, Afrodisis 1977), preventing ancient freshwater well (inv. no. S. 173), late Hellenistic in date, was found to the north, at the agora of Paphos, with a similar groundwater level reached at $0.95 \mathrm{~m}$ asl (Miszk 2020: 142). Together with the fact that the sea level might have changed since ancient times, the above findings make it difficult so far to recognise the original, ancient groundwater level, water quality, and the wells' potential location in the limits of Maloutena without dedicated microregional studies.

${ }^{17}$ A detailed study of these installations is the subject of the author's $\mathrm{PhD}$ thesis and will be published separately. 
and literature on the subject provide little comparative material ${ }^{18}$ to understand these installations the author was forced to rely above all on the knowledge of the general hydraulic principles, well-established methodological practices ${ }^{19}$ and his own careful field observations and analysis of the archaeological context of the finds. The most important assumptions applied in the research are listed below:

1) all the ancient water conduits operated by gravity, ${ }^{20}$ thus their inclination determined their flow direction unless they were pressurised as a part of a siphon allowing them to deliver water uphill;

2) the presence of the intentionally cut apertures in the pipes precludes the pressurisation of the pipeline, ${ }^{21}$ suggesting its solely gravity flow, with possible exceptions in case of apertures blocked with stoppers applied from the inner side of the pipe (see the case of PP7 below);

3) the muff (male end) in spigot-socket-form pipes is always oriented into the direction of the flow; ${ }^{22}$

4) the character of the filling of the pipeline may suggest its function (e.g. grey, clayish fill in case of waste; emptiness in case of rainwater or sinter in case of spring water);

5) the presence of the sinter deposit (calcium carbonate) inside the pipeline indicates it carried the 'hard', spring water (i.e. abundant in minerals, in contrast with the 'soft' rainwater); ${ }^{23}$

6) a range of sinter within the pipes indicates the average level of the flow - its presence on the whole inner diameter indicates the pipeline was fully filled with water and thus pressurised.

With the above assumptions in mind, the pipelines were examined in terms of their archaeological and architectural context, course, inclination, muff-orientation, methods of construction, maintenance modifications, filling, spatial and functional interrelations, and types of pipes they were composed of. Among the pipes discovered at the site, eight types

18 As Femke Martens (Martens 2001: 62, n. 66) rightly points out, neither of the two most important sources, Vitruvius' De Architectura and the Frontinus’ De Aqueductu Urbis Romae, pays special attention to the morphology of the urban water distribution and disposal system.

19 Martens (Martens 2001: 62, n. 64) warns against false assumptions, unsupported by the archaeological evidence, such as that the 'smaller pipes are for supply, whereas larger pipes serve the purpose of drainage' (referring to Crouch 1984: 359-360), and 'the generalisation that pipes are for supply, whereas built channels are constructed for drainage'.

${ }^{20}$ Mark E. Landon (Landon 1994: 368 cit. per Palinkas, Herbst 2011: 314, n. 58) noted the gradient of $0.114 \%$ (a fall of $0.04 \mathrm{~m}$ over a distance of $35 \mathrm{~m}$ ) is sufficient to allow the water to flow through the pipe without added pressure.

21 Hodge 2002: 114; Palinkas, Herbst 2011: 314, n. 58.

22 Forbes 1964: 153; Hodge 2000: 41. Field observations, however, show that in the pipelines combined of different pipe types (usually of reused pipes of different shapes and sizes) this rule is not always followed, and muffs' orientation is not constant within one line, as is exampled by PP27.

${ }^{23}$ Sürmelihindi, Passchier 2013: 274-275, Fig. 2. Notabene sinter does not have to always be deposited as the water may have lost its mineral content earlier on its way from the source or if there were no conditions conducive to the deposition. 
are discussed here. They were distinguished based on their shape, dimensions, ceramic mass (fabric) ${ }^{24}$ and special features like potters' marks (Figs 3-4, Tables 1-2). ${ }^{25}$

In many cases, the full on-site examination of the objects in question was impossible. Some of them were known only from vague mentions in archival documentation and archaeological reports, while those still accessible in the field formed usually a chain of pipes so closely interconnected that only their external appearance could have been analysed. ${ }^{26}$ In fact, the greatest amount of data was obtained from destroyed parts of pipelines, giving a chance to recognise, at least partly, the cross-sections of the pipes, their joints and the kind of material filling their interior. Where it was possible, the interior of the unexcavated parts of pipelines was inspected with a long-cable endoscope camera to examine their further course and possible branches.

\section{RESULTS}

THE PIPES

As mentioned above, from among the pipes discovered at the site, eight types were distinguished. Almost all the pipes (Figs 3-4, Table 1) were of the spigot-socket form (male end - female end), in which narrowed male flange fit into a female opening with a stop, apart from type 7, which had just a thickened lip at the end(s). The types preserved in the greatest number - among which were types 1, 2 and 3 - had characteristic hourglass, helically ridged bodies. Type 5 had an hourglass body with a smooth surface. In types 4 and 8 , bodies were of a slight hourglass shape, while type 6 belled in the middle, all with a smooth or slightly undulating surface. Type 7 was belled at the end(s) but cylindrical in the middle body, with a smooth surface, occasionally helically ridged in the middle. All of them were made on a pottery wheel as the helical ridging suggests, visible especially on the inner surface. The spigot-socket forms usually have the male end consisting of a slightly rounded shoulder and a cylindrical flange thickened toward the flat lip. The female end consisted of a stop - pinched up in types 1-4 and 6, and built up of the body in type 5 - and a flange ${ }^{27}$ thickened toward the flat lip. Type 8 stands out a little by more trapezoidal body widened at the male end, the shoulder smoothly transformed into a flange, and a barely noticeable pinched up stop. Numerous pipes, not presented here, are combinations

${ }^{24}$ The methodology of the pipe examination was inspired mainly by the studies of Jennifer Palinkas and James A. Herbst (Palinkas, Herbst 2011) on the pipes from Corinth, of Jordan Pickett (Pickett 2016) on those from Ephesus and of Kai Wellbrock on those from Pergamon (Wellbrock 2012).

${ }_{25}$ The intention of the author was not to present here the complete catalogue of the pipes from Maloutena but the choice of the most common and/or characteristic types, which were accessible to closer examination. The other types of pipes are to be classified and presented in the following stages of the project.

${ }^{26}$ The length of the male flange, thickness of the walls and some other values were available to measure only in single cases thus have been omitted in above general characteristic of pipe dimensions. These values, however, taken from the cross-sections pictured in Fig. 3, were placed in the Table $\mathbf{2}$ as the indicative, exemplar ones.

27 The term 'female flange' is used here to describe the part of the female end located between the stop and the lip. 


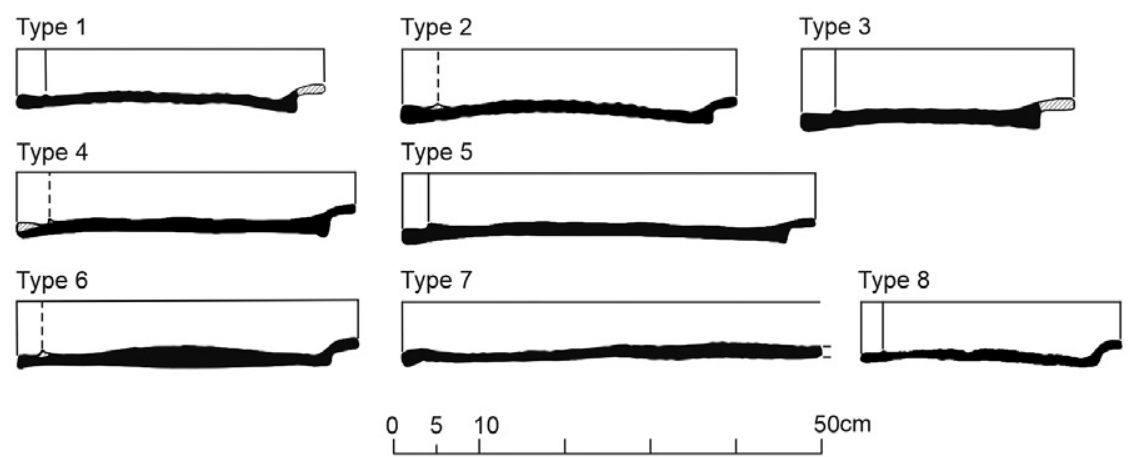

3. Cross-sections of examples of pipes representing particular types; diagonal and dashed lines indicate the reconstructed fragment of the pipe based on the shape of similar pipes (Drawing: M.M. Romaniuk).

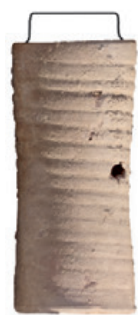

Type 1

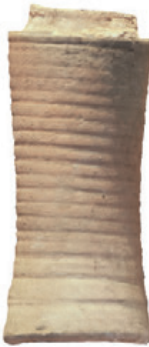

Type 2

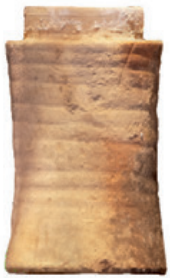

Type 3

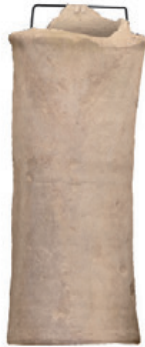

Type 4

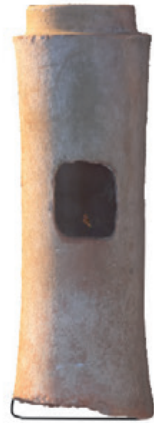

Type 5

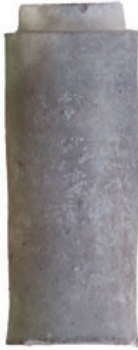

Type 6

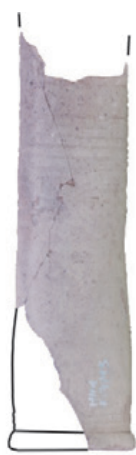

Type 7

$0 \quad 5 \quad 10$ $50 \mathrm{~cm}$

4. Orthophotos of the examples of pipes of particular types; dark solid lines indicate reconstructed fragments of the pipe. Type 8 is not presented due to the fragmentary preservation (Phot. and processing: M.M. Romaniuk).

of the above general characteristics, with the one exception of a spigot-socket pipe made unique by its large, cylindrical body encircled with three, regularly distributed bands found at the main entrance of VT (PP37).

The dimensions of the pipes (see Table 2) range from 26 to $c .49 \mathrm{~cm}^{28}$ for the body length, and from 14.2 to $20.5 \mathrm{~cm}$ for the outer body diameter. All the types have an elongated body in general, although type 3 is more heavyset. The length of the pipes does not exceed the length of a human forearm, which relates possibly to the wheel-made production ${ }^{29}$ and/or to desire to enable application of mortar inside the joints when installing the pipelines.

Most commonly, the fabric of the pipe material (see Table 3), as noticed for pipe types 1-2, 4 , and 7-8, was hard, harsh in texture, in various shades of yellow, pink, red and brown colours, with prevailing abundant, medium to very large spherical sub-rounded and angular

\footnotetext{
${ }^{28}$ Maximum value relates to the pipes from PP2 and PP3, not classified in typology, and PP46 (type 7).

${ }^{29}$ Hodge 2002: 113.
} 
inclusions (excluding type 1 , in which small to medium size inclusions predominate), manifested often as irregular dark spots visible on the surfaces..$^{30} \mathrm{~A}$ similar fabric seems to be testified for the transport amphora as well as for pipes and other ceramic building materials found at the agora of Nea Paphos and considered to be of local provenience. ${ }^{31}$ The fabric of type 6 was hard and harsh, of dark reddish-brown core and pinkish-grey surface, of more granular break, with more varied inclusions. The pipes of type 3 and 5 were made of less harsh fabrics, of reddish yellow and various shades of brown colours, granular in a break, with the domination of fine to medium size inclusions, especially the white ones, which appears abundantly on the smoothed surface of the pipes of the latter type.

Some of the pipes bore marks intentionally made before baking. On both (the only two known) pipes of type 6 (PP39) the handwritten Greek inscriptions AKEC were observed, but of different styles of letters (Fig. 5a-b), ${ }^{32}$ which may suggest they were not made by the same man, thus possibly showing the name of the workshop owner or some individual that commissioned construction of the conduit. Another inscription - EY - was found on unclassified pipe (Fig. 5c). The meaning of these inscriptions remains unclear so far, as no analogy has been found. ${ }^{33}$ Moreover, there were also geometrical potter's marks noticed on two pipes of type 4, depicting three circulars in a triangular configuration, possibly made with a stamp (Fig. 5d), and also with no analogy known to the author.

Considering the chronology of presented types of pipes, or rather the pipelines (see the section Chronology of the pipelines, below) that they were incorporated in, the material can be divided into two groups: 1) early Roman pipes, types $1-7,{ }^{34}$ dated between the mid-first century and the first half of the second century AD, and 2) late Roman pipes, type 8 and unclassified here pipes from the pipelines of VT and its entrance platform, dated to at least the fourth century AD. Although the dating of the pipes from the first group seems to be reliable, as they were found apparently in their primary context, within the well-made pipelines homogenous in terms of types of pipes used, the dating of the pipes from the latter group is uncertain as they were incorporated in carelessly made pipelines, often of the various types of pipes, possibly reused..$^{35}$ These later pipes (apart from type 8 ) in general give an impression of being more massive and less carefully made.

30 The description of the fabrics in Table 3 conform to the system used by Guy D.R. Sanders (Sanders 1999: 477-478).

31 Dobosz 2020: 329.

32 At one of two pipe of type 6 the epsilon and lunate sigma are rounded, while at the second one they are angular. At least on one pipe the alpha has a broken bar (it is unclear on the second one), which gives the beginning of the second century $\mathrm{BC}$ as a terminus post quem for the manufacturing of these pipes (Mitford 1971: 94, 112).

${ }_{33}$ The only example of inscribed terracotta pipes from Cyprus, known to the author, comes from Amathus, and bears a Greek inscription LB ADRI[anou], suggesting the renovation works of the Hellenistic aqueduct by emperor Hadrian in his second year of his reign (see webpage Roman aqueducts and Aupert 2009: 41-42, Fig. 14).

34 Some doubts occur in case of chronology of the pipes of type 3 (see below).

35 Pickett (Pickett 2016: 298) notes a similar phenomenon in Ephesus, suggesting that it was 'a manifestation of multiple pipe manufacturers working as contemporaries and contractors on the same project' or 'an indication of stockpilling and reuse of pipes for repairs, perhaps considerably after the date at which the pipes were originally produced'. 

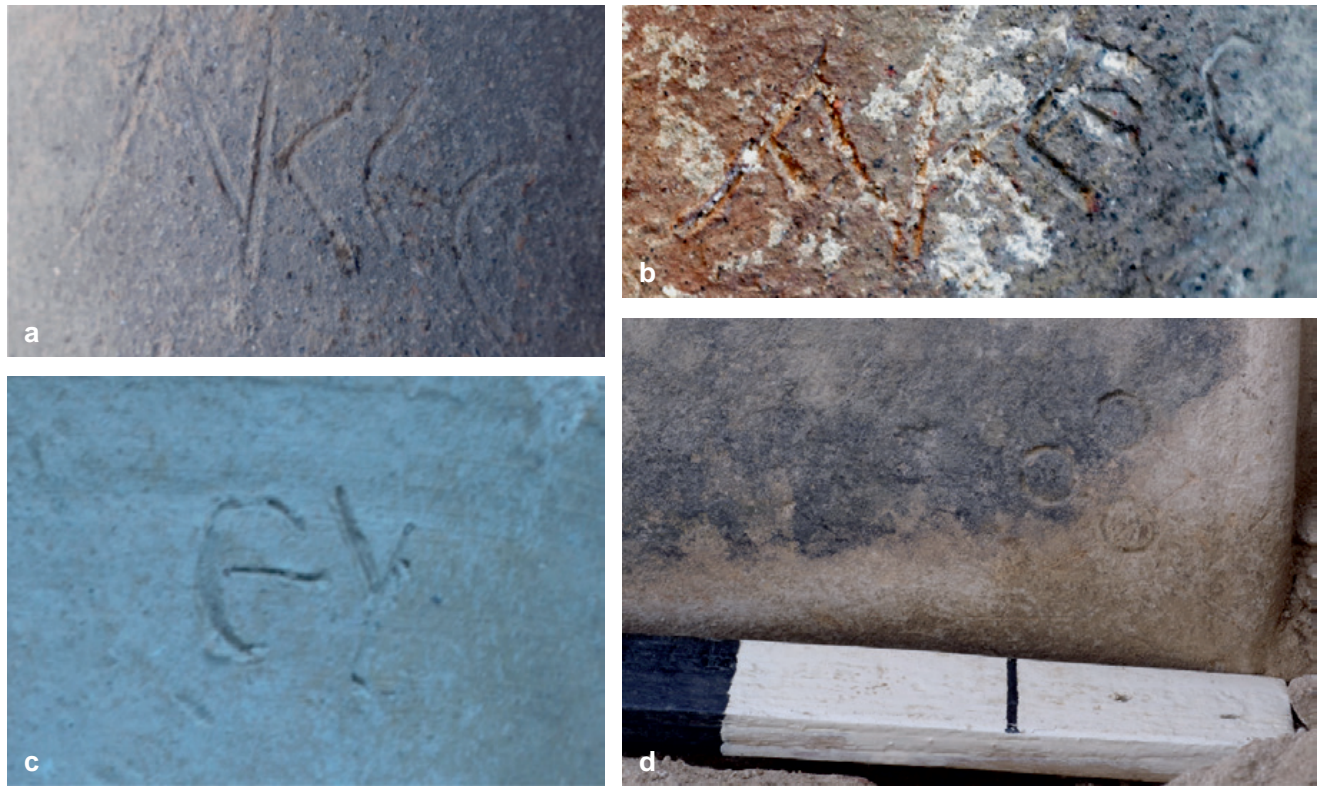

5. Inscriptions and potter's mark on the pipes: a-b. inscriptions AKEC on the pipes of type 6; c. inscription EY on the unclassified pipe type (context unknown); d. geometrical potter' mark (triple circle) on the pipe of type 4 (a-b, d. Phot. M.M. Romaniuk; c. Archive of the Polish Archaeological Mission in Nea Paphos)

Terracotta pipes were encountered also in the other spots of Nea Paphos, and some of them seem to resemble the types from Maloutena. ${ }^{36}$ The spigot-socket (male-female) type pipe with remains of lead counterpart set into it was found by the Australian expedition next to the Antonine proscenium wall of the theatre - at the foot of the Fabrika hill in the north-eastern part of the city ${ }^{37}$ - and seems to correspond to the type 1 due to its helically ridged, hourglass-shaped body. Similarly shaped pipes, corresponding to type 1 or 2, occurred in the conduit found by the French mission (MafaP) close to the Hellenistic mosaic discovered in 1995 south-west of the Fabrika hill. ${ }^{38}$ Other spigot-socket form pipes are known from the excavations of the Polish mission of the Jagiellonian University conducted at agora of Nea Paphos; some of these pipes seems to have ribbed body as those of types $1-3 .^{39}$

${ }^{36}$ Numerous pipes can be seen also in various spots of the HO, however, this material was not published thus was not included in the comparison.

${ }^{37}$ Green, Stennett 2002: Fig. 13.1; Barker 2007-2008: 43, Fig. 9.

38 Balandier 2017: 229-230, Fig. 15.

${ }^{39}$ Rosińska-Balik 2020: 191; Miszk 2020: 159, Pl. 24; only a few dimensions of the pipes were given; for those from the pipeline marked as S.119: $35 \mathrm{~cm}$ in length (of the body?) with slight differences in proportions (around $18 \mathrm{~cm}$ in diameter, judging by the plan attached), while for those from the S.131: $46 \mathrm{~cm}$ in length and $17-18 \mathrm{~cm}$ in diameter. 
Noteworthy are also the 'clay water pipes' embedded in the rock-cut channel noticed by Kyriakos Nicolaou in the area of the North-West Gate..$^{40}$ They were of the spigot-socket type, brick-red colour and thick walls, which were admittedly not observed in situ at Maloutena, but where the fragments of similar pipes were found in the Hellenistic contexts, suggesting their relatively early date. Additionally, in nearby Kouklia (Palaepaphos) a pipe analogous in dimensions and shape to type 2 was found - the pipe was named $\mathrm{KV}^{41}$ Its chronology, unfortunately, was not specified, nevertheless, such similarities may suggest its provenance from the same, local manufacturer. Beyond the Paphos area, the terracotta pipes can be still observed at numerous other ancient urban sites in Cyprus, e.g. Amathus, Salamis or Kourion, although only those from the last site have been published in more detail. ${ }^{42}$

\section{CONSTRUCTION AND MAINTENANCE OF THE PIPELINES}

Pipelines were installed in shallow ditches, just below walking level, to facilitate later access when requiring a repair. Such placement was possible due to the local climate conditions excluding freezing of the ground. ${ }^{43}$ The lines were composed of the spigot-socket pipes joined by placing the muff (the male end) of one pipe into the widened end (the female end) of the next. The joints were sealed with mortar skimmed on the inside to a smooth surface, with fingers as the imprints suggest (Fig. 6). This material is extremely hard and tightly adhered to the pipe surface, ensuring the durability of the connection. It was white lime with almost no inclusions, possibly corresponding to the mortar recommended by Vitruvius, made of the clarified burnt lime mixed with water and oil ${ }^{44}$ which expands when in contact with water. ${ }^{45}$ The conduits were flanked with stones, evidenced in PP2 (Fig. 8c), PP3 (Fig. 8d), PP4 (Fig. 8f), PP7 (Figs 7b, 10c, 11a), PP11 (Fig. 11d), PP12 (Fig. 10d), PP33 (Fig. 9b) and PP43 (Fig. 9g) for better stabilisation in the ground. The method of installation of PP46 is unclear, as it is represented only by the one loose pipe of type 7 found in debris of the southern portico of HH1 (Figs 7e, 12b). ${ }^{46}$

The lateral tributaries and the elbows, observed in PP2 (Fig. 8c), PP11 (Fig. 11d) and PP39 (Figs 7c, 13e), were realised by fitting the muff of the pipe into the aperture cut in the side of the next pipe. In the elbows, the further pipe was blocked on its female end with stone or ceramic sherd sealed with mortar. As for now, no one-element elbow pipes have been observed. Other direction changes could have been achieved also through the

40 Nicolaou 1966: 576.

41 Last 1975: Table C, Pl. XII.

42 Last 1975, including some details on terracotta pipes from Kouklia.

43 Crouch 1984: 359.

${ }^{4}$ Vitr., De arch. VIII.6.8. Małgorzata Biernacka-Lubańska (Biernacka-Lubańska 1973: 132, 277) uses a term 'malta' or 'maltha' for this type of mortar.

45 On the sealing materials, see: Malinowski 1996.

${ }^{46}$ Marking of this pipe(line) in the Fig. 2 relates to the place where the pipe was found. 


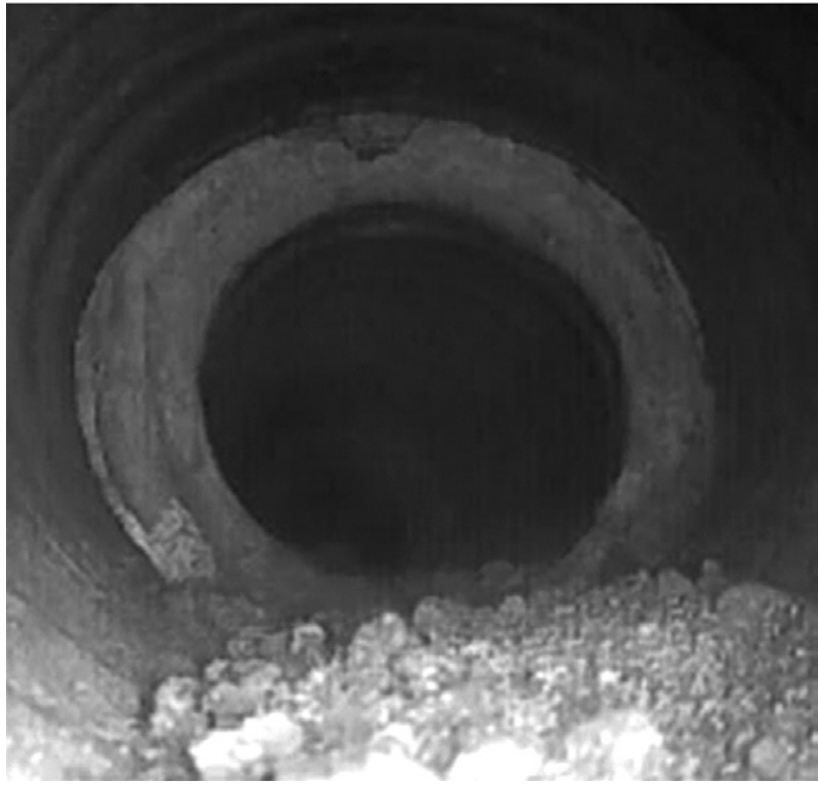

6. Fingerprints impressed in the inner mortar sealing of the joint between pipes; picture taken with an endoscope camera (Phot. M.M. Romaniuk).

settlement/distribution box, as observed in PP6 (Figs 10c, 12b), analogical to those from Kourion and its vicinity. ${ }^{47}$ Additional solution is to lead the pipeline widely along a curved course, as is illustrated by PP21, PP24 and PP37 (Fig. 10a-b, e).

Some of the pipes had the oval or rectangular apertures of hand-size (or smaller) chipped in their tops, a phenomenon well known from many other sites, often considered as inspection holes, to facilitate sealing, cleaning or repairing the pipelines. ${ }^{48}$ In PP40 at least eight such holes were observed (Figs 7a, 9d). Three of them were apparently made to facilitate better internal sealing of the joint between incompatible elements, as two were made in two adjoined pipes of different diameters, while the third one was in the pipe that was cut into halves and recomposed of these two pieces set in reverse order (Fig. 7a). The other five holes in PP 40 may have been made for a similar purpose. All of them were to be closed with stone or ceramic stoppers in mortar, still preserved in some cases (Figs 7a, 9d). Another pipe with a hole was observed in PP7 (the only case in the entire line), evidencing possibly unsuccessful and/or unskilful repair (Fig. 7b). The pipe was removed once and placed again in its original spot in a half-turned position, with the joints left unsealed, while the hole was closed with a pipe fragment put on the inside, in contrast to other recorded stoppers applied from the outside (an attempt to strengthen perforation of a pressurised line?). Undoubtedly, the conduit was leaking thereafter and went out of use.

${ }^{47}$ For elbow pipes, see: Last 1975: 50, 53, Fig. 7: P17, Table C: P17, Pls VI: 23, XII: P17; for junction/ distribution/settlement boxes (tanks), see: Last 1975: 44-46, 54, Fig. 1: 3-4, Tables A, E, Pls I: 3-4, III: 10, 12, IX: 35, X: 37.

${ }^{48}$ For more information and references on this topic, see, e.g.: Jansen 2000: 106, n. 8; Hodge 2000: 41; 2002: 114 , n. 46 . 

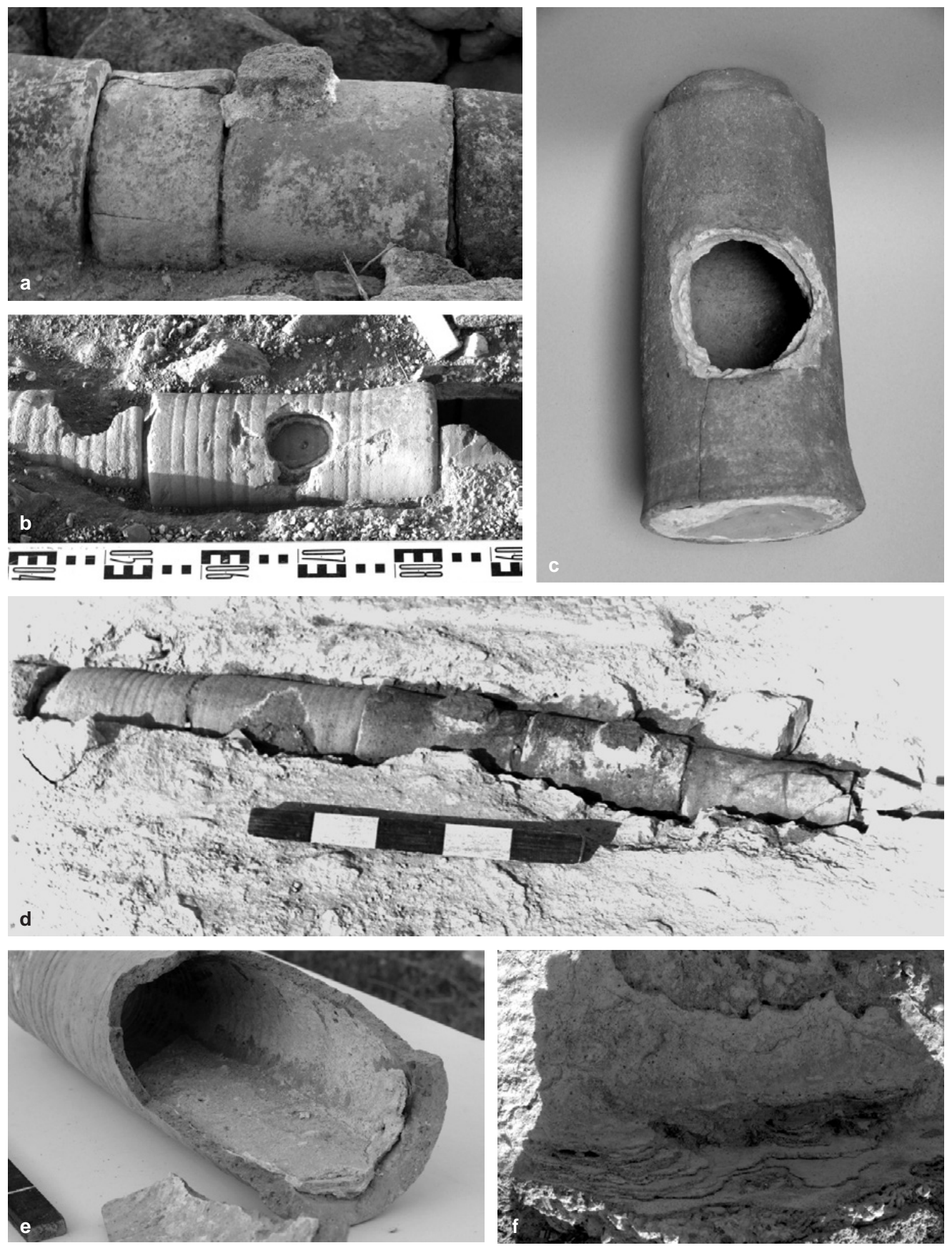

7. Apertures, stoppers and sludge within the pipes: a. PP40, stone stopper closing the aperture in the pipe made of two parts (northern view); b. PP7, terracotta stopper closing the aperture in the pipe (northern view); c. PP39, receiving part of the elbow with an aperture at the side, female end closed with pottery sherd; d. PP27, stone stoppers closing the apertures in the pipes (north-western view); e. PP46, pipe of type 7 with sludge inside; f. sludge in the gutter of the cornice from HH13 (a-b, e-f. Phot. M.M. Romaniuk; c-d. Archive of the Polish Archaeological Mission in Nea Paphos). 

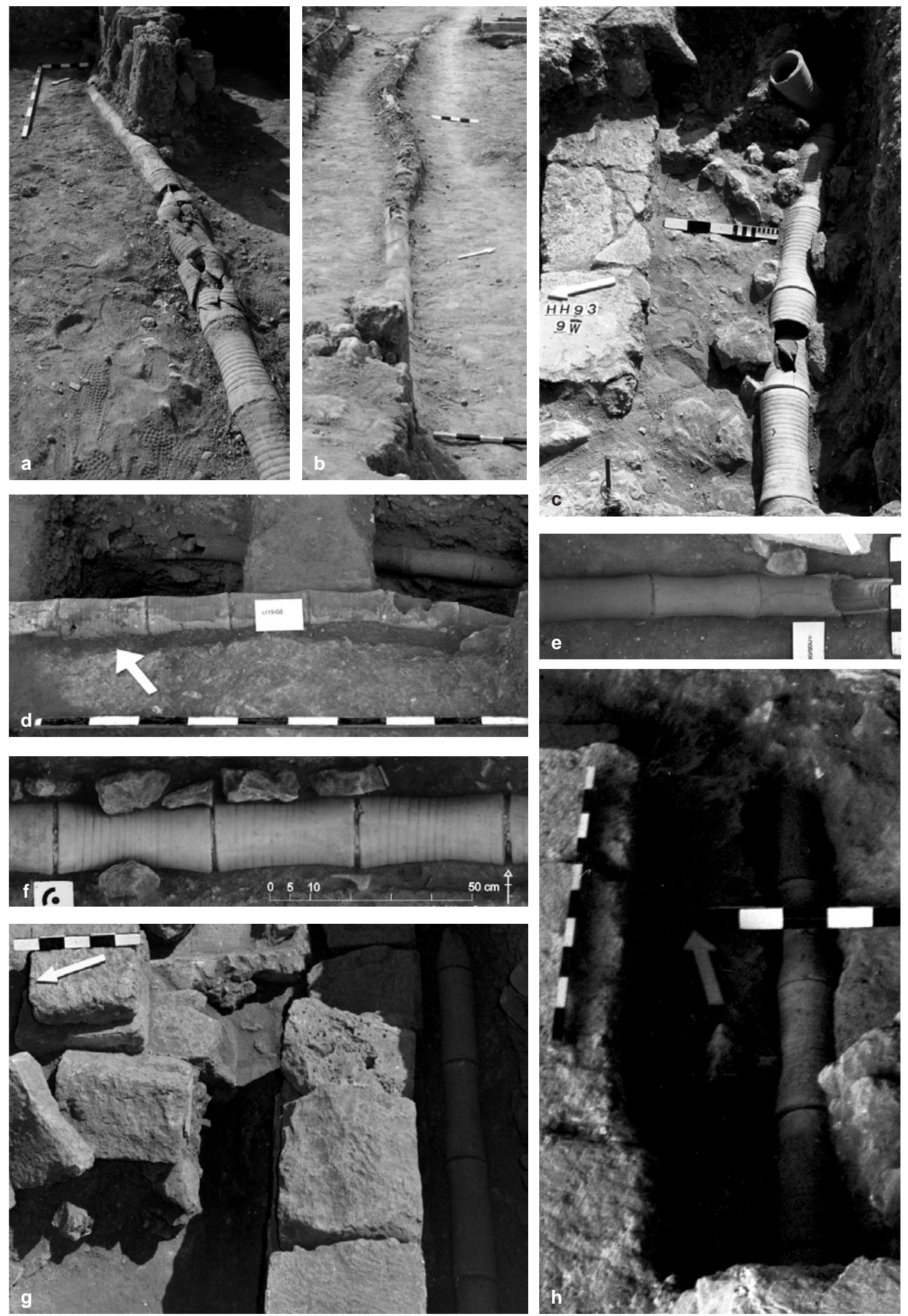

8. Pipelines of the first group: a. PP1 (eastern view); b. PP1 (western view); c. PP2, PP2.1 (eastern view); d. PP1, PP3 (northern view); e. PP22 (northern view); f. PP4 (orthophoto plan); g. PP5 (eastern view); h. PP31 (northern view) (a-e, g-h. Archive of the Polish Archaeological Mission in Nea Paphos; f. Phot. and processing M.M. Romaniuk). 

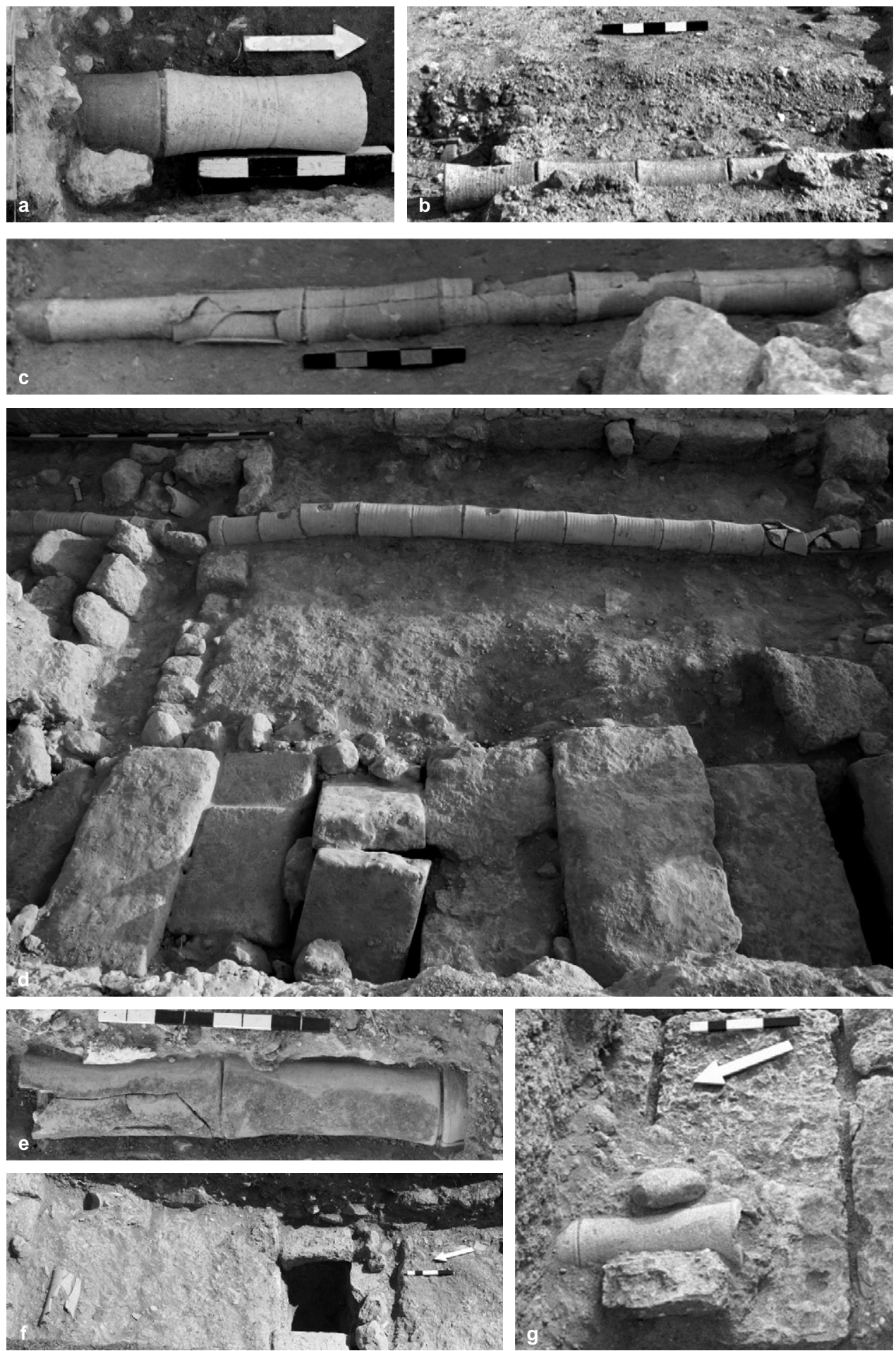

9. Pipelines of the first group: a. PP32 (western view); b. PP33 (eastern view); c. PP34 (northern view); d. PP40 with street sewer and side drain (northern view); e. PP42 (eastern view); f. PP44 (eastern view); g. PP43 (eastern view) (a-d, f-g. Archive of the Polish Archaeological Mission in Nea Paphos; e. Phot. M.M. Romaniuk). 

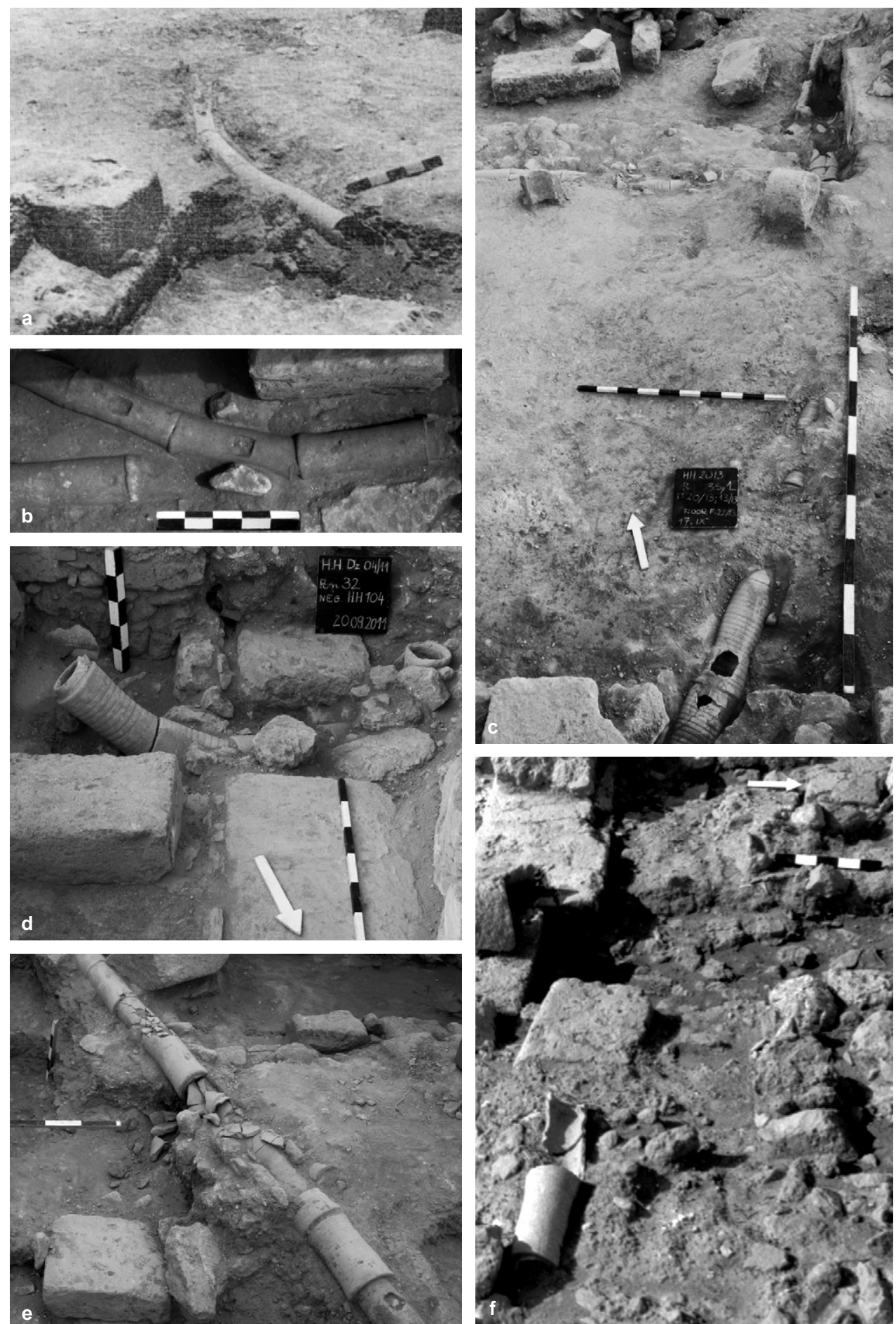

10. Pipelines of the second group: a. PP21 (north-western view); b. PP23 (at the bottom), PP24 (at the top; southern view); c. PP6, PP7, settlement/distribution tank (northern view); d. PP12 (southern view); e. PP37 (southern view); f. PP41 (western view) (a. Młynarczyk 1990: Phot 29; b-f. Archive of the Polish Archaeological Mission in Nea Paphos). 

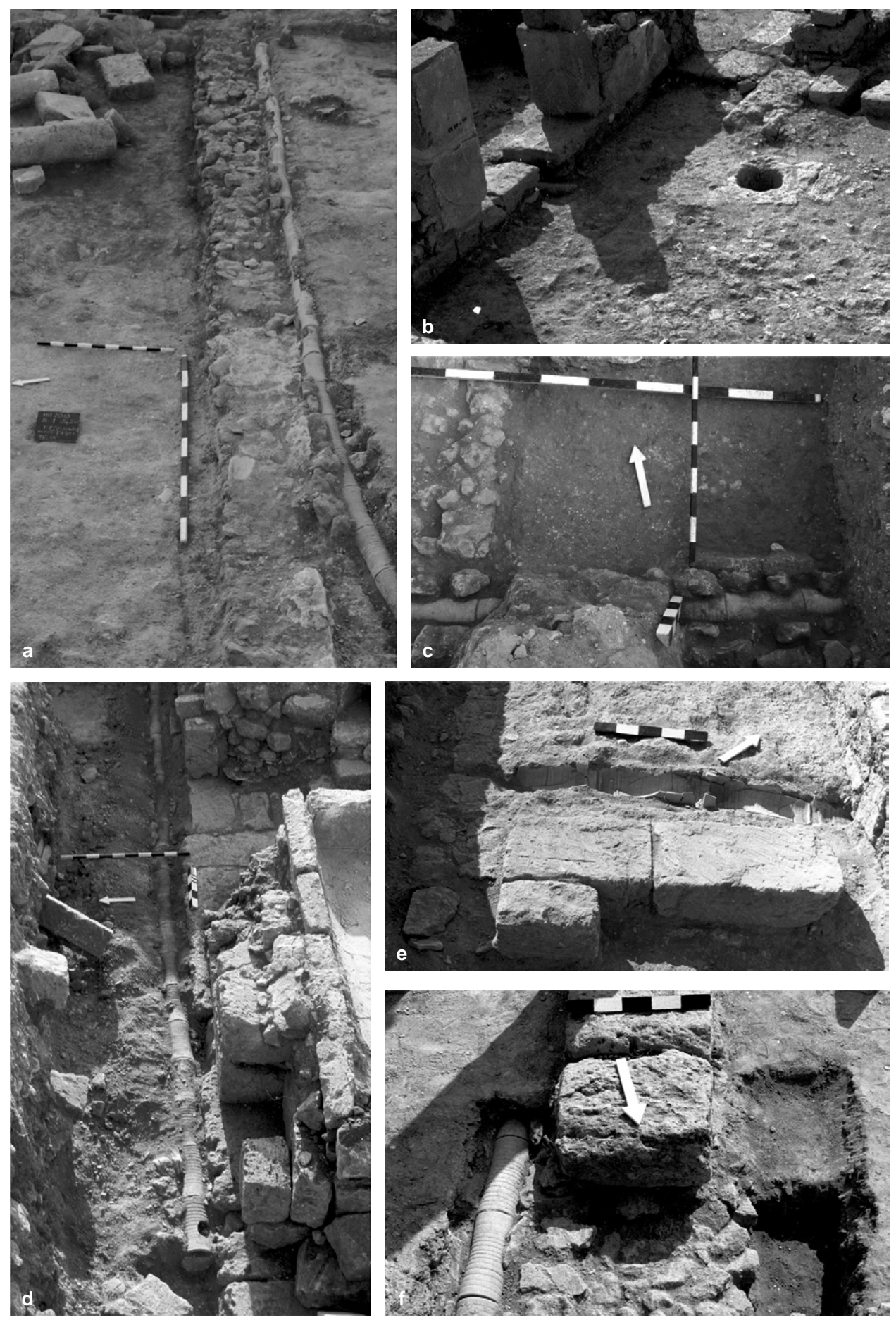

11. Pipelines of the third group: a. PP7 (eastern view); b. PP8, PP9 (south-western view); c. PP10 (northern view); d. PP11 (eastern view); e. PP14 (western view); f. PP15 (southern view) (a-f. Archive of the Polish Archaeological Mission in Nea Paphos). 

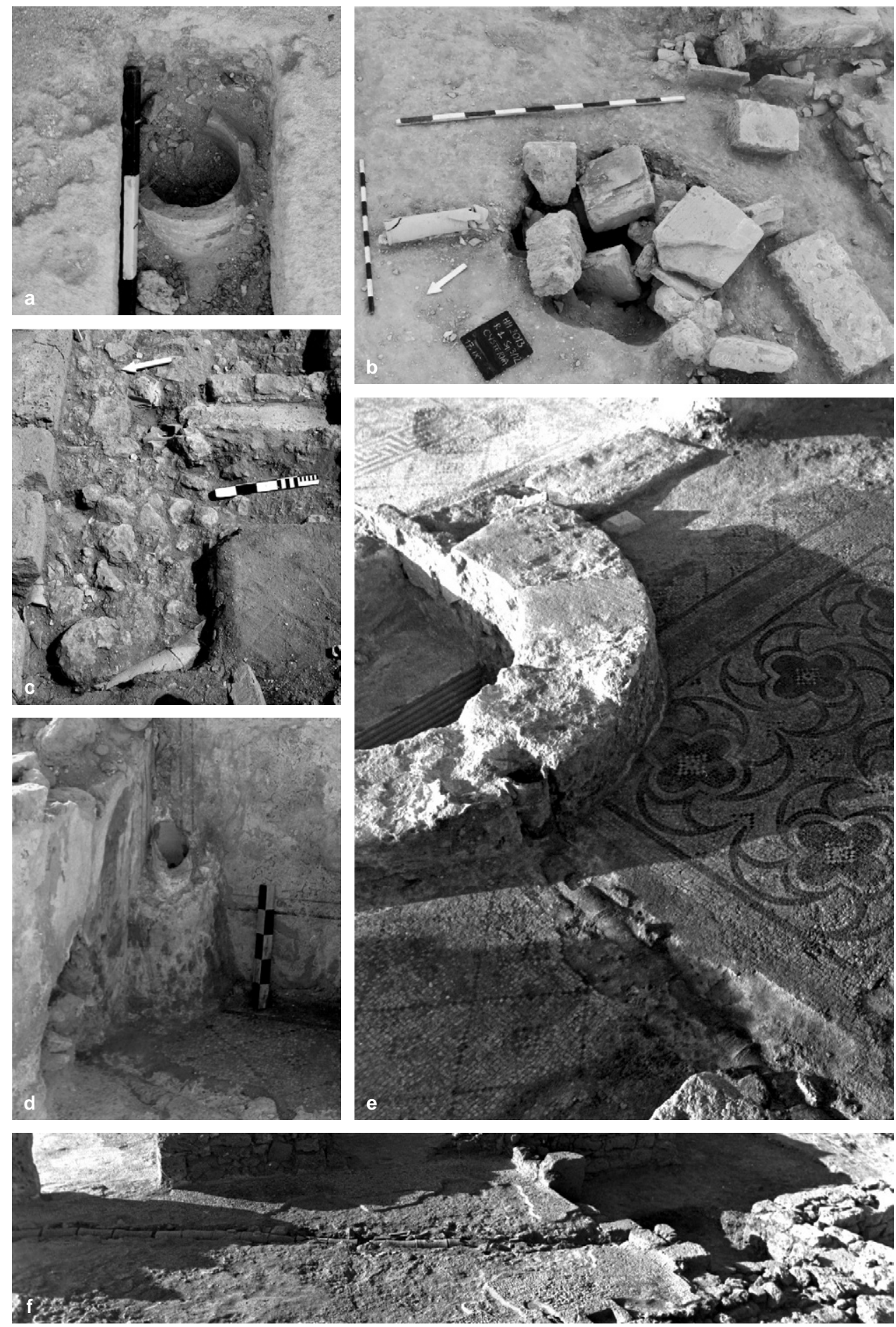

12. Pipelines of the third group: a. PP16 (western view); b. PP46, pipe of type 7 to the left of the cistern shaft, PP6 and settlement/distribution tank in the top right corner (south-eastern view); c. PP17, PP18, PP19 (eastern view); d. PP25, PP26 (south-eastern view); e. PP25 (north-western view); f. PP27, to the right: corner of the rectangular cistern/well (western view) (a. Phot. M.M. Romaniuk; b-f. Archive of the Polish Archaeological Mission in Nea Paphos). 

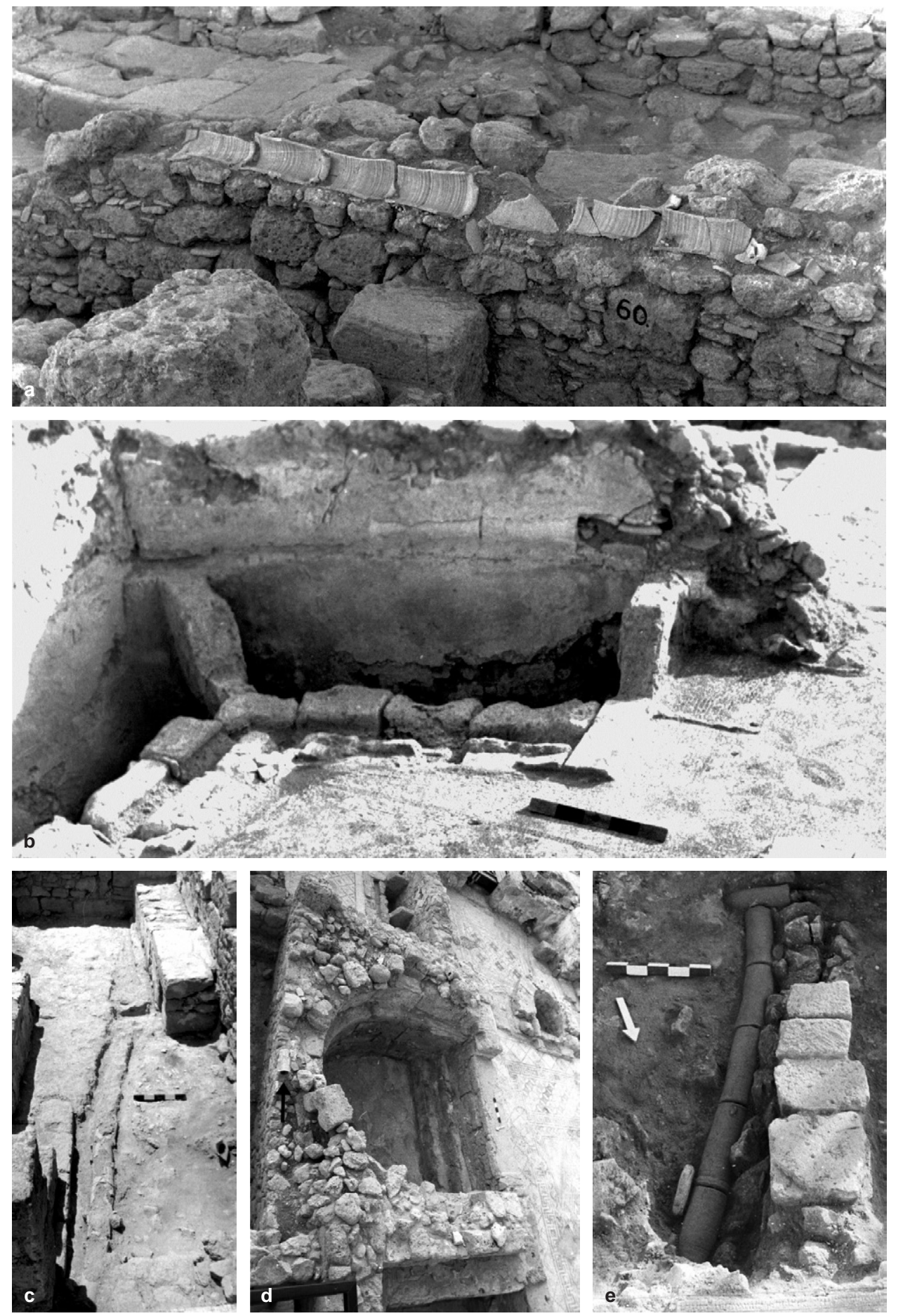

13. Pipelines of the third group: a. PP28 (north-western view); b. PP29 (eastern view); c. PP30 (southern view); d. PP45 (marked with a black arrow, eastern view); e. PP39 (southern view) (a-e. Archive of the Polish Archaeological Mission in Nea Paphos). 
Two joined pipes located in the much-curved point of PP24 also had apertures, possibly to facilitate better internal sealing of hardly accessible curved spot, probably more prone for fault due to not so tight fitting of the pipes contrary to straight-line joints (Fig. 10b). A similar situation appeared in PP37, in which, however, the general reason for making the aperture must have been again to facilitate the joining of pipes differing in size (Fig. 10e), as in PP27 (Figs 7d, 12f).

No sinter deposits were testified inside any of the investigated pipelines. Exclusively the pipe of type 7 had a kind of layered sludge inside, however, of different nature than the sinter (Fig. 7e). In general, the conduits were empty inside or filled partly or fully with sediment of apparently post-depositional character. ${ }^{49}$

\section{SPATIAL DISTRIBUTION AND THE FUNCTION OF THE PIPELINES}

The pipelines recorded at Maloutena may be divided into three main groups according to their location and direction (Fig. 2, Table 4). The first group represents the primary pipelines running along the streets; ${ }^{50}$ the second includes the secondary pipelines running between the streets and the buildings, and the third, the pipelines located in the frame of the buildings.

Sections of the first group were found on the Street A: PP22 (Fig. 8e); Street A': PP1 (Fig. 8a-b), PP2 (Fig. 8c), PP3 (Fig. 8d), PP4 (Fig. 8f), PP5 (Fig. 8g); Street B: PP34 (Fig. 9c), PP35, PP40 (Figs 7a, 9d); Street C: PP44 (Fig. 9f), and Street 9: PP31 (Fig. 8h), PP32 (Fig. 9a), PP33 (Fig. 9b), PP42 (Fig. 9e), PP43 (Fig. 9g) following the orthogonal layout of the city. ${ }^{51}$ Their flow directions and inclinations ${ }^{52}$ seem to be overall consistent, from north to south at the meridional Street 9, and from east to west at the latitudinal streets, excluding PP2 and PP3 oriented from west to east. PP1, possibly a continuation of PP4 due to a similar type of pipes (type 2) used, was running slightly meandering through the middle of the street. It was empty inside, without apertures (thus pressurised?), and with no side tributaries over a distance of almost $27 \mathrm{~m}$, thus possibly was a freshwater supply, maybe delivering water to the fountains or water towers in the crossroads of the streets. However, the lack of sinter traces, usually left by 'hard' spring water from the limestone

49 'Post-depositional sediment' is understand here as all the sediments deposited inside the pipeline after it went out of use and not related to its original function.

${ }^{50}$ Part of these pipelines were found in the limits of the rooms of the VT. They, however, undoubtedly preceded erection of VT, thus the conclusion they originally were located on the streets.

51 The systematic pipeline network following the regular, orthogonal layout of the streets, was characteristic for the Hellenistic urban water systems, known from e.g. Priene, Rhodos-town and Lindos (Jansen 2000: 109, n. 18).

52 According to Młynarczyk (Młynarczyk 1990: 166), Street 9 was sloping from south to north in line with the gradient of the terrain. In general, however, it must have inclined from north to south as it was continuing along the western elevation of the House of Dionysos (further as HD; Młynarczyk 1990: 166) up toward the Fanari hill. Regarding the sloping of Street B, from west to east towards the port as Młynarczyk (Młynarczyk 1990: 173) suggests, is questionable in light of the author's measurements of the top level of the slabs covering the under-street canal (most likely indicating the original level of the streets) implying opposite direction of inclination with average level difference of about $11 \mathrm{~cm}$ at the distance of $c .100 \mathrm{~m}$. 
karstic region of Paphos, raises some doubts, and thus rainwater or light wastewater draining function can not be excluded definitely. PP2 was apparently a drain collecting run-off from the roof at the southern façade of $\mathrm{HH}$ as suggested by the presence of the downspout PP2.1. PP40 could have been a drain replacing the main sewer under Street B ceased to function yet in antiquity. ${ }^{53}$ It was cut by a stone-built channel leading from HA to the main sewer, that was apparently still used in places as a soak pit (Fig. 9d). It seems probable that this construction is a later modification of PP40 (for chronology see below), and possibly this pipeline was originally a supplying line. Other pipelines of the first group are preserved/available insufficiently for closer examination.

Regarding the pipelines of the second group, they were found running from Street A: PP20, PP21 (Fig. 10a); Street A': PP2.1 (Fig. 8c), PP6 (Fig. 10c); Street 9: PP23 (Fig. 10b), PP24 (Fig. 10b), PP41 (Fig. 10f); Street 10: PP12 (Fig. 10d); and Street B/Late Roman Street: PP36, PP37 (Fig. 10e), PP38. PP41 was probably a drainage due to its inclination and flow direction from the west curb toward the sewer in the middle of Street 9. PP36 of similar function had a form of vertical pipe running from the top of the entrance platform of VT down to the sewer under Street B. PP37, low-quality constructed of reused and not well-fitted pipes with apertures, was sloping down through this entrance to the Late Roman Street, most likely draining water from the vestibule. PP6, although could be ascribed also to the third group due to the fact it was found entirely within the frame of a building, was placed in the second group, as it was connecting Street A' with HH. Apparently, it was transferring rainwater from PP2 and PP3 made of likely the same type of pipes as PP6. ${ }^{54}$ PP12, entering the HH from the west, was going bent upwardly, which would suggest it was pressurised supplying for the upper storey. This hypothesis, however, is uncertain, because the pipeline has no visible structural support, thus the question arises as to whether this structure could stand on its own when exposed to pressure forces..$^{55}$ The vertical pipe adjoined to its horizontal part without a proper joint (a lack of the sealing traces or nest hole, apart from a small irregular hole) as maybe a secondary makeshift modification to a drain is also confusing. PP23 and PP24, of which the latter cut the former, were running beyond the eastern carb of Street 9 possibly delivering fresh water to the building, as the run-off collecting drain would rather run closer to the wall of the supplied building, judging per analogiam to PP2, PP3 and PP6. Other pipelines of the second group are preserved/available insufficiently for closer examination.

53 Daszewski et al. 2010: 504. It seems that most of the under-street drains had ceased to function by the beginning of the second century AD (see: Młynarczyk 1990: 170-173). It cannot be excluded that some of them had gone out of use earlier, which is suggested by the presence of the possible settlement tank/soak pit built at Street A', close to the southern wall of room RH1. It was draining into the ground - through two outlets made of terracotta pipes - the waste water delivered from the basin north of the RH2 by the stone channel under RH1. The tank was filled up with material comparable with this attested in destruction layers of the HD, dated to the third decade of second century AD.

${ }^{54}$ Pipe type with elongated, ribbed body, similar to type 2, but larger: body length $c$. 45-49cm and diameter c. $18-19 \mathrm{~cm}$.

55 Usually such constructions, i.e. the siphons, were strengthened with stone, brick or concrete structures (see the water towers in Discussion below). 
The pipelines of the third group appeared in HH: PP7 (Figs 10c, 11a), PP8 (Fig. 11b), PP9 (Fig. 11b), PP10 (Fig. 11c), PP11 (Fig. 11d), PP13, PP14 (Fig. 11e), PP15 (Fig. 11f), PP16 (Fig. 12a), PP17 (Fig. 12c), PP18 (Fig. 12c), PP19 (Fig. 12c), PP46 (Figs 12b); VT: PP25 (Fig. 12d, e), PP26 (Fig. 12d), PP27 (Figs 7d, 12f), PP28 (Fig. 13a), PP29 (Fig. 13b), PP30 (Fig. 13c), PP45 (Fig. 13d); and HA: PP39 (Fig. 13e).

In the first building, three pipelines - PP11, PP13 and PP16 - were probably the drainage due to their downspouts. PP11 was running along the southern wall of the Western Courtyard towards the east. Its first pipe from the west had the female end blocked with a stone stopper, and a circular nest for the unpreserved downspout running possibly through the niche in the nearby wall. PP13 was found in the north-eastern corner of the Western Courtyard (HH13). It was preserved only in a few pieces of the lowest pipe of the downspout, through which water was running to the ceramic funnel and next by the stone channel presumably to a rectangular cistern at the west part of the courtyard. PP16, placed in the niche cut in the stylobate of the eastern portico of the Main Courtyard (HH1), had a form of a narrow deeply ribbed pipe installed vertically with an eastward inclination. It may have been intended for draining rainwater from the roof and/or of the surplus water from the rectangular reservoir located in the south-east corner of the courtyard. Another possible drain, PP14, located in the north-western corner of the Main Courtyard, may have been draining water to the north from the large rectangular pool located to its south. ${ }^{56}$ PP7 and PP15, running - respectively - to the east along the southern stylobate and the north along the eastern stylobate, made of the same type of pipes (type 1), belonged possibly to the same conduit. This cannot be, however, verified as the continuation of the first line disappeared after its intersection with PP6. Possibly PP10 in HH29 was the beginning of PP7, as it was made of the same type of pipe (type 1) and running at the same level. These two sections may have been connected by PP8 and PP9. If this hypothesis is right, then the absence of tributaries, relatively constant level on over 35m-long distance (measuring from PP7 to PP10), small diameter of the pipes ${ }^{57}$ used and lack of the apertures (apart from the one discussed above), may suggest that it was a supplying line, maybe even pressurised. It seems less probable that it was a run-off drain as it is questionable if water could successfully flow on such distance without inclination. Moreover, its length would be incomprehensible, as to drain the water to the nearby streets or cisterns it could be led on the much shorter course. PP6, of which chronological and structural relation with PP7 cannot be determined due to the poor state of preservation of their intersection, was running through the settlement/distribution tank located in the south-east corner of the Main Courtyard (HH1). This tank was distributing water (from PP6, see above) in two directions: to the west - probably to the large rectangular basin - and the north - possibly to the small circular pool. ${ }^{58} \mathrm{PP} 46$ (pipe type 7) - found nearby - was most likely the gutter of the southern portico of HH1.

56 Meyza et al. 2017: 401, 403-404, Figs 2-4 (inv. nos S.2/14, S.20/16).

57 As stated earlier, diameter should not be taken by itself as a criterion for interpreting pipe functions, but in combination with other indicators it can be helpful. Small diameter pipes seem to be more prone to obstruction if they would carry waste, thus the conclusion is that they belonged rather to the supply line.

${ }^{58}$ For details about these pools, see: Meyza et al. 2017 and Romaniuk 2017. 
This is suggested by the place it was found, and the layered sludge resembling gritty mortar inside the pipe (Fig. 7e). It was identical to that observed in the gutter of the cornice blocks of the Western Courtyard (Fig. 7f), being possibly the deposit taken by water flowing from the mortared flat roof. Other pipelines from $\mathrm{HH}$ are preserved/available insufficiently for closer examination.

Another cluster of the third-group pipelines was found in the bath complex of VT..$^{59} \mathrm{In}$ apodyterium (VT64) two pipelines, PP25 and PP26, the first going downward in the back wall of the semicircular basin and continuing through the mosaic floor to the eastern wall, and the latter running downward in the thick-walled mortar sleeve in the south-eastern corner of the room, were possibly drainage. The first was probably to drain surplus water from the semi-circular basin and the latter for rainwater from the roof. They both were likely connecting with horizontal PP27, which runs through the mosaic floor to the northern wall of another apodyterium (VT67), being most likely directed toward the large rectangular cistern/well in VT68. ${ }^{60}$ Another possible drain was the horizontal PP28 built-in in the north wall of the latrine (VT60), made of pipes of type 8. Possibly in this group also PP29 should be included, incorporated into the eastern wall of this room with inclination toward the south. It was made of the pipes (unclassified here) similar to ones from the vertical drains in the apodyterium VT64. Putting aside the question of whether these two pipelines were connected at some point in the north-eastern corner of the latrine, at least the latter could lead to the round hole cut in the first stone support of the seats, to flush the north-east part of the latrine sewer or to supply small water channel in front of the seats. As for now, no second-group pipelines have been testified to feed the baths with the freshwater from the external supply. Thus they might have relied on the water from the mentioned cistern/well in VT68 ${ }^{61}$ Other pipelines from the VT are preserved/available insufficiently for closer examination. ${ }^{62}$

The last pipeline of the third group is PP39 from the HA, running under the mosaic of HA1, from north to south and turning east. Possibly it drained wastewater from the mosaic or water surplus from a cistern in the HA15. ${ }^{63}$

\section{CHRONOLOGY OF THE PIPELINES}

Analysis of the archaeological context shows that the pipelines of the first and second group, apart from those from the Street B/Late Roman Street, correspond with early Roman street

59 Daszewski 1976: 194-206.

${ }^{60}$ Daszewski 1976: 204. Muffs' orientation within PP27 is not constant but most of the muffs seem to be oriented toward the VT68.

${ }^{61}$ For brief discussion on the possible function of this feature, see above footnote 16 . If it was a well with saline water then the hypothesis about feeding the baths by it is doubtful.

62 Noteworthy, terracotta pipes in the VT were used not only to transport water but also to channel hot air through the walls of the bath building and outside of it, as is suggested by the negative of ribbed-body pipe incised in the concrete back wall of the semicircular basin in the southern wall of VT62.

${ }^{63}$ Karageorghis 1987: 687, Fig. 39; 1988: 837, Fig. 77. 
levels, from the mid-first century to the first half of the second century AD. They may have possibly occurred in several phases, as PP2 and PP3 were found in the context overlying PP1 and PP4, while PP23 was cut by PP24. The discrepancy occurs in the case of PP34, under which were found numerous fragments of a mosaic dated by its stylistic to the turn of the second and third century AD. ${ }^{64}$ However, the considerable depth at which the pipeline appeared and the type of pipes used ${ }^{65}$ may suggest an earlier date. Another discrepancy occurs in the dating of the PP40, as it is associated in general with the second-century-AD context, but in places this chronology can be moved even to the fourth century AD, possibly associated with later modifications of the line. Considering the pipelines from Street B/Late Roman Street (PP36, PP37), they must have been later, related with the erection of the $\mathrm{VT}$ in its final appearance in the fourth century AD.

Apart from PP19, PP20 and PP21, for which the context was dated to the second/first century BC, the periodisation of the pipelines of the third group is similar to the two other groups. The pipelines found in the limits of the HH may be dated between the mid-first century to the first half of the second century AD, with emphasis on the second half of the first century AD as the time of their installation. Those from the VT must have been later, as they were laid during the rebuilding of the residence and establishing of the baths in its south-eastern corner some time in the fourth century AD. In the case of the PP39 from the HA, only terminus ante quem can be tentatively suggested to the middle of the fourth century $\mathrm{AD}$ due to the dating of the mosaic overlaying the pipeline. ${ }^{66}$

\section{DISCUSSION}

\section{The PiPelines of Maloutena AND the Water Supply of NeA Paphos}

Attempting to specify the periodisation of the early Roman pipelines from Maloutena some suggestions may be given concerning a chronology of the pipelines discovered at the agora of Nea Paphos. The two earliest ones were to be installed during Julio-Claudian's reign (27 BC-AD 68), ${ }^{67}$ while the later one was after the earthquake of the Flavian times ${ }^{68}$ It seems that these installations, both from Maloutena and the agora ${ }^{69}$ were destroyed at the same time, along with surrounding structures, due to the massive earthquake, which was to ruin also the nearby $\mathrm{HD}$, that occurred in the second century AD, possibly in $\mathrm{AD} 126 .{ }^{70}$ This catastrophe must have struck a vast part of the city and caused serious damage

${ }^{64}$ Information obtained from archival documentation.

${ }^{65}$ It was similar to type 2, but more elongated (c. $41 \mathrm{~cm}$ long and c. $14-15 \mathrm{~cm}$ wide) and with a ribbed body.

${ }^{66}$ Karageorghis 1985: 954.

${ }^{67}$ Miszk 2020: 148-149; inv. nos S.131 and S.182.

${ }^{68}$ Rosińska-Balik 2020: 191; inv. no. S.119.

${ }^{69}$ Miszk 2020: 152; the given date relates to the time when rooms 1 and 2 - to which the pipeline S.119 was associated - finally went out of use.

${ }^{70}$ Hayes 1977: 96. For alternative dating - closer to the half of the second century AD - see article on the weight from agora in this volume (Łajtar 2021). 
to urban infrastructure, with the water system at the forefront, as is additionally evidenced by the fact that at the same time a number of Hellenistic sub-street sewers and underground cisterns/wells at Maloutena, ${ }^{71}$ as well as at the agora, ${ }^{72}$ were filled up.

Considering the organisation of the early Roman water network at Maloutena, it seems that the inhabitants relied heavily on rainwater supplies, which were collected and distributed over the buildings possibly for feeding decorative pools, ${ }^{73}$ gardening, ${ }^{74}$ bathing ${ }^{75}$ or storage in the cisterns for further use. Some of the pipelines, however, running through the streets (PP1 and PP4) and within HH (PP7, PP8, PP9, PP10, PP15) could have also transported fresh water from the aqueduct, but this assumption is uncertain due to the lack of sinter deposits inside them. There is no doubt, however, that the city was once provided with an aqueduct supply - as suggested by its numerous elements found within and around the city ${ }^{76}$ - delivering water probably from the area of Tala, $c$. $8.5 \mathrm{~km}$ north of the city, through Lemba and Chlorakas. ${ }^{77}$ In the Roman urban water system model in general, water from the aqueduct was reaching the distribution tanks located at the elevated points of the city, from which, through castella divisoria, was to be distributed to the different consumers in the city, that is especially the street fountains, baths and private houses. ${ }^{78} \mathrm{In}$ the case of the Nea Paphos, such points were at the Fanari hill (c. 20m asl) to the north and Fabrika hill (c. $24 \mathrm{~m}$ asl) to the north-east from Maloutena (Fig. 2).$^{79}$ The latter hill is considered by Jolanta Młynarczyk to be the best spot for the outlet of a water supply system, a pressure tower to channel the water further into several directions ${ }^{80}$ The rock-cut underground cisterns (floor level at $12 \mathrm{~m}$ asl) found at Fanari, of which the date was not specified, were fed by the side branch of the rock-cut aqueduct running through the hill (floor level at $16 \mathrm{~m}$ asl). The inlet and side outlet of this channel are still visible at, respectively, the north and the east slope of the hill. ${ }^{81}$ Conceivably it was related to the pipeline

${ }^{71}$ Only a few of the underground cisterns/wells (from around forty known) located at the investigated area were explored. Excavations show that most of the cisterns appeared in the Hellenistic period and were forgotten already during the habitation phase of VT (Młynarczyk 1990: 185, 189-190).

72 Miszk 2020: 145.

73 Meyza et al. 2017; Romaniuk 2017; see below, footnote 90.

${ }^{74}$ Possibly after the rebuilding of $\mathrm{HH}$ in the end of the first century AD (Brzozowska 2016: 46, n. 3) at the Main Courtyard (HH1) the garden was established (Daszewski 1994: 104-105; Meyza et al. 2017: 400, 405, 413).

75 See below pages 391-392 and footnotes 59 and 105, as well as Rekowska et al. 2021, in this volume.

76 For information on the remains of the ancient aqueduct found in the vicinity of Paphos, see: Hadjisavvas 1977: 227-228.

77 For general discussion and references on the aqueduct supply in Nea Paphos, see: Młynarczyk 1990: 222-223; for some update on aqueduct at Fabrika, see: Bessac 2016: 108-109, Figs 3-4; Balandier, Guintrand 2016: 137-138, Figs 39-43.

${ }^{78}$ For general discussion and references on the Graeco-Roman urban water system model, see e.g. Jansen 2000; Wilson 2008: 293-309.

${ }^{79}$ Both elevations according to Google Earth (accessed September 16, 2021).

80 Młynarczyk 1990: 223.

${ }^{81}$ Młynarczyk 1996: 198, Fig. 5. Additionally, at the top of the Fanari also the open-air, rectangular, rock-cut cistern can be seen. 
running on the modern top (c. $8 \mathrm{~m}$ asl $)^{82}$ of the city wall near the North-West Gate, mentioned above. ${ }^{83}$ The pipes bear the sinter deposit inside indicating they were a part of the freshwater conduit, maybe of Hellenistic date. In the case of Fabrika, south of the theatre, two meters below the ground level, the terracotta pipelines ran as well, although their date is not precised. ${ }^{84}$ It seems possible these pipelines were related to clay pipes found during excavations of the Department of Antiquity east of the King Mall Avenue in 2014, which may have been a part of a Hellenistic and Roman-era aqueduct. ${ }^{85}$ The cistern on the Fabrika, supplied most likely with the stone-slab-covered channel running from the north, allegedly functioned in the second century AD. ${ }^{86}$ It seems too late, then, to relate it with the Maloutena pipelines of the early Roman phase, although the mentioned date is given as a time of utilisation of the cistern, which does not exclude the possibility that it had appeared earlier. Whether these pipelines could have indeed been supplied by an aqueduct then? As for now, it cannot be ruled out that a Hellenistic aqueduct existed at the time of construction of Maloutena pipelines, and was still exploited, renewed by subsequent rulers, as is illustrated by the later activity of emperor Hadrian in Amathus. ${ }^{87}$ As Cassius Dio stated emperor Augustus was to provide Nea Paphos with funds for postearthquake reconstruction, ${ }^{88}$ thus a renovation of the earlier waterworks may also have occurred. On the other hand, the mid-first century AD was a time when numerous cities in the Roman Imperium were provided with new aqueducts by emperor Claudius, among them at least three Cypriot cities - Kyrenia, Salamis, and Soloi - as can be ascertained from epigraphic material. ${ }^{89}$ It seems quite possible then that Nea Paphos, a priority as the capital and most important city of Cyprus at that time, would also obtain an adequate water supply, if needed. An interesting fact is that in the first century AD ornamental water devices appeared in Nea Paphos, such as the circular pool in the Main Courtyard of the $\mathrm{HH}^{90}$ and the nympheum nearby the Theater at the foot of Fabrika hill. ${ }^{91}$ The foundation of such installations are often associated with the introduction of an aqueduct providing an abundant

82 According to Google Earth (accessed September 16, 2021).

${ }^{83}$ See above, page 373, footnote 40.

${ }^{84}$ Peristianis 1927: 37 cit. per Młynarczyk 1990: 222, n. 263. The depth at which the pipes were discovered relates to the ground level from the twenties of the past century (as noted by Peristianis).

85 See webpage CyprusMail; Raptou 2016: 60-61, Fig. 13.

${ }^{86}$ Balandier, Guintrand 2016: 137.

87 See above, footnote 33.

${ }^{88}$ Cass. Dio., Historiae LIV.23.

${ }^{89}$ Skevi Christodoulou (Christodoulou 2015: 231-232) briefly discusses three inscriptions related with these waterworks. For Kyrenia, see: Mitford 1950: 17-18, no. 9; for Salamis, see: Nicolaou 1963: 48-49, no. 12; for Soloi, see: Mitford 1950: 28-31, no. 15.

90 Romaniuk 2017. The question of how this pool was fed, with constantly flowing freshwater or water stored in cisterns, is still open. Although it seems to have been fed with rainwater by PP2, PP3, PP6, these lines may have carried at the same time water from an aqueduct. The freshwater would be more preferable for fish, which were probably bred in this pool (Romaniuk 2017) rather than stagnant water from cisterns, which would have to be used during dry periods.

91 Barker 2016: 99. 
water supply and thus enabling usage for purposes exceeding basic needs, as in Pompeii. ${ }^{92}$ All these presumptions may suggest the introducing of a new (or additional) aqueduct supply to the city still in the first century AD, which would have enabled the spreading of Roman water culture among the local community. According to Frontinus, ${ }^{93}$ obtaining a water connection required approval from the Emperor himself, which implies that only wealthy and influential persons were able to obtain such a privilege. Thus, if to assume that indeed the $\mathrm{HH}$ was supplied with the water from the aqueduct, possibly by PP6, PP7, PP8, PP9, PP10 and/or PP12, it would be in line with the suggestion made by Młynarczyk that the building might have been the seat of the Roman governors of Cyprus during the first century AD. ${ }^{94}$

While continuing technical considerations on the early Roman aqueduct, the question is whether the water delivered to Maloutena could have been flowing through the pipelines by pressure. The lack of the sinter does not allow for an easy answer. What can be ascertained, however, is the slope of the potentially freshwater supplying pipelines, PP1 and PP4, achieving $68 \mathrm{~cm}$ on a distance of $45 \mathrm{~m}$, equal to $1.5 \mathrm{~cm} / 1 \mathrm{~m}$, which is much more than sufficient for effective gravity flow. ${ }^{95}$ As to whether the pipelines may have been pressurised, a clue may be provided by the triple-perforated cuboid stone blocks, fitted together in a spigot-socket pattern, discovered in the Western Courtyard of the HH (Fig. 14a-b). They have been interpreted to date only as reused parts of the siphon, possibly belonging to a castellum aquae, leading the water through three parallel conduits diverged in three different directions with its last, base segment. ${ }^{96}$ A block similar to this base block and dated to the Julio-Claudian dynasty's reign was found at the agora of Nea Paphos. It had a triple perforation oriented upwards and specially profiled furrow for a horizontal pipe branch visible on the top of the succeeding stone blocks on one of its sides. ${ }^{97}$ It seems more likely to the author that the pillars made of such blocks (Fig. 14c) may have been originally crowned with small tanks - up to which one conduit was bringing water, while two others drained it downward - and indeed functioned as small water towers (i.e. pressure towers). They were working possibly the same way as those in Pompeii ${ }^{98}$ or Palmyra ${ }^{99}$ (Fig. 14d)

92 Jashemski 1992: 111. The introduction of the aqueduct made possible the more generous use of water resulting in the appearing of the decorative pools and fountains in the Pompeian gardens, which became their characteristic features.

${ }^{93}$ Aq. 99.3, 103.2 and 105.1.

94 Młynarczyk 2016: 34.

95 See above, footnote 20.

96 Daszewski 1994: 108; Meyza et al. 2012: 415-416, Fig. 9.

97 Miszk 2020: 147, 148; Rosińska-Balik 2020: 191; inv. no. S.125. Possibly of similar character was a square block that can be observed in the west wall of north portico of the agora in Amathus. It had two vertical conduits, of which one was leading to the east side, while the second was divided into two branches, north and west, the latter blocked with a stone stopper.

98 Jansen 2000: 113; Hodge 1996: 271.

99 Juchniewicz, Żuchowska 2012: 66, Fig. 10; 2013: 346, Fig. 5. For reconstruction of Palmyra water tower, see: Kessener 2020: Figs 5b, 6. 

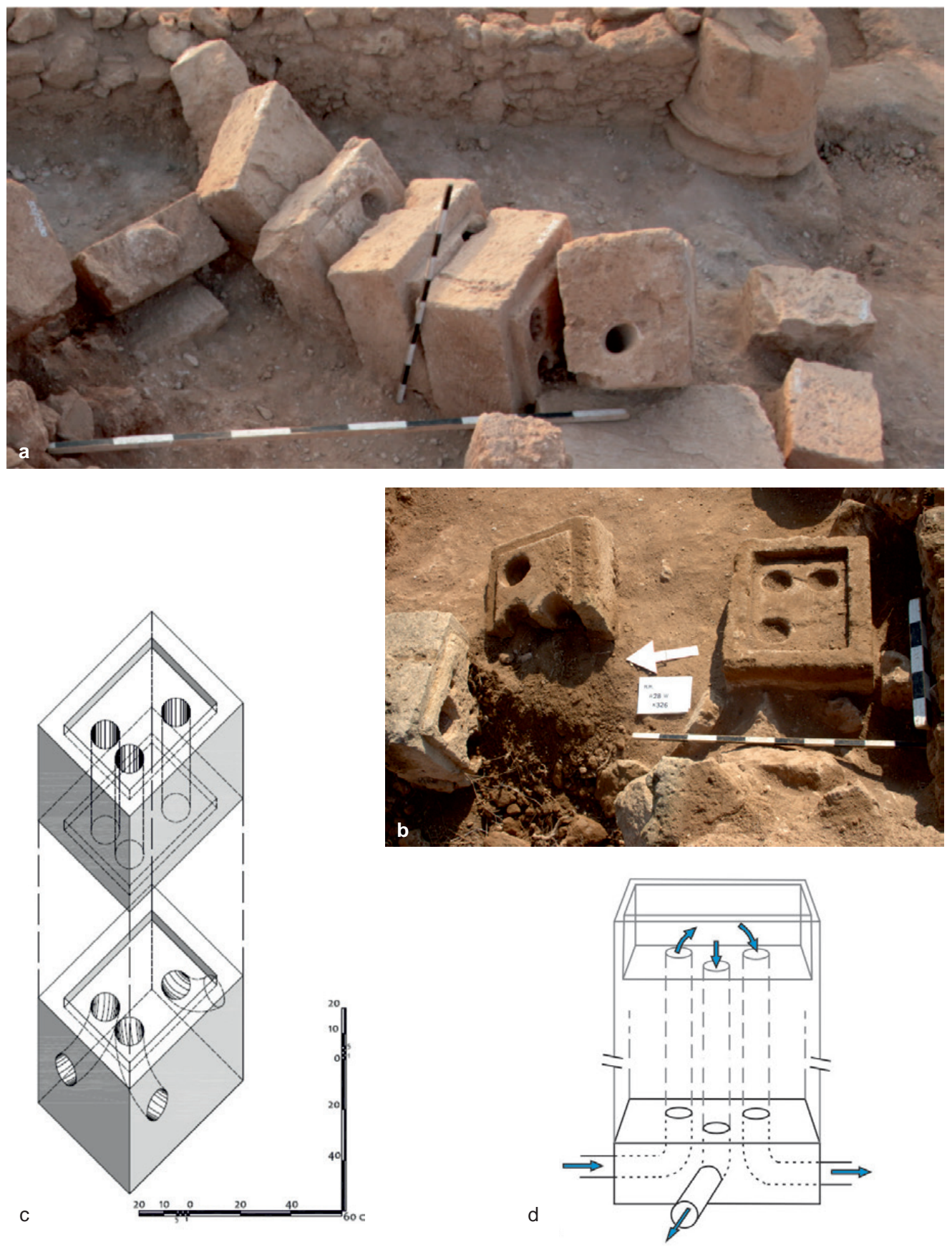

14. Water tower (siphon): a. blocks of siphon found in HH13 (eastern view); b. blocks of siphon found in HH28W (eastern view); c. reconstruction of the siphon tower from HH13; d. reconstruction of the water tower from Palmyra (a-b. Archive of the Polish Archaeological Mission in Nea Paphos; c. drawing: A. Brzozowska; d. drawing: M.M. Romaniuk; based on: Kessener 2020: Figs 5b, 6). 
but were made of prefab components, which facilitated their construction and control of the water pressure within the pipeline by reducing or increasing the tower height through adding or removing blocks from its top. These blocks, however, were found at Maloutena in a secondary context, thus it can not be said whether and when such devices were originally installed in this area. It is also uncertain if all these blocks constitute a complete set that would allow the reconstruction of the original height of the tower. Nonetheless, it can be assumed at least that they were used within the city at the time in question.

The diameter of the male ends of the investigated spigot-socket pipes was well fitted to the diameter of the conduits cut in the siphon blocks $($ c. $11-13 \mathrm{~cm})$. Additionally, the earthenware pipes were also proved to withstand an inner pressure up to 50atm, ${ }^{100}$ much more than around 1atm, which would be achieved by differences in height between the hill of Fanari (c. 20m asl) and Maloutena (modern ground level c. 10m asl; ancient level c. 8-9m asl) and slightly higher from Fabrika (c. $24 \mathrm{~m}$ asl). ${ }^{101}$ Considering the above, it can be concluded that the early Roman pipelines at Maloutena might have been pressurised.

Regarding the pipelines of the late Roman phase, their function seems to be limited to collecting the rainwater and draining it to the cisterns or out of the building. Most of them constituted a water network of the baths. Some were also found in the other spots of VT, however, their late date is questionable (PP34, PP35; Fig. 9b-c). To date, despite the large-amount-water-consuming installations in VT, like the assumed nympheum in VT71/72 ${ }^{102}$ and baths in the south-eastern corner of the building, ${ }^{103}$ there was no evidence found for their being supplied with extramural freshwater. One explanation for this can be that the late Roman freshwater lines were not preserved, especially if they were running into the walls like the pipelines in the latrine VT60 (PP28, PP29) or were made of lead. ${ }^{104}$ An alternative explanation would be that after the destruction of the earlier freshwater network it was never restored and the area was supplied entirely with water from wells (if existed) and rainwater stored in cisterns. The latter solution is very likely, as numerous bath complexes found elsewhere in Cyprus were also fed mainly with stored

100 Forbes 1964: 153. At Priene the terracotta pipes with a wall thickness of $1.5 \mathrm{~cm}$ - similar to the investigated ones (see Table 2) - withstood the atmospheric pressure of 11.5atm (Wiegand, Schrader 1904: 72)

101 For Digital Surface Model (DSM) of Nea Paphos (Kato Paphos), see: Ostrowski et al. 2020: Pl. 144.

102 Structure interpreted as a nympheum (water fountain) (Daszewski 1998: 11; Daszewski, Michaelides 1988: 53; Medeksza 1992: 41; 1998: 35) consisted of three elongated rectangular basins in the U-shape set around rectangular podium in the western end of the entrance passage (VT71/72), open to the peristyle courtyard of VT (Daszewski 1976: 210).

${ }^{103}$ Apart from the bath in VT, the small bath was also introduced in the south-west corner of the $\mathrm{HH}$, dated so far to the late second and third century AD (Christou 1994: 683; Daszewski 1995: 72). It seems probable, however, that it was built earlier along with the nearby settlement tank/soak pit; see above, footnote 53).

104 At the sites first occupied by the Greeks the terracotta pipes were preferable over lead ones (Jansen 2000: 119, 121). There are, however, some examples of use of the lead pipes in Nea Paphos, like the one still visible in a basin (south of VT62) in the baths of VT (Daszewski 1976: 202) or by the proscenium wall of the theatre at Fabrika (see above, page 372, footnote 37). Lead, as a material, was willingly robbed from the sites and reused, especially in the areas where it was scarce, thus lead elements rarely preserved in situ. 
water. ${ }^{105}$ What can additionally support this hypothesis is the appearance of the stone-built cisterns in VT48B ${ }^{106}$ and HA15 and the reuse of some Hellenistic ones. Nonetheless, the aqueduct at Fabrika was apparently still working to some extent at that time providing water for the nearby Theatre adapted to accommodate the nympheum and water spectacles. ${ }^{107}$

\section{CONCLUSIONS}

Examination of the Maloutena pipelines shows that their network was well organised, carrying water along the orthogonal streets to the buildings equipped with their own indoor pipeline network. The pipelines were used both for supply and drainage, often joining these functions by draining rainwater to the cisterns. It seems that from the beginning, for the inhabitants of Maloutena (and Nea Paphos) the rainwater harvesting (possibly along with the drawing of water from the wells and local streams) was a primary source of water, as the cisterns were used even when the city was provided with an extramural aqueduct. The aqueduct was introduced most likely already in the first century AD or even earlier, in the Hellenistic period, and water could have been distributed over the city through the pressurised pipelines, as is suggested by the relics of the water towers. The abundance of water provided by the aqueduct allowed the inhabitants to equip their houses with water-consuming devices like ornamental pools or baths, hence not objects of necessity but a manifestation of their status and wealth, as well as affinity to Roman culture. As a result of the earthquake that occurred in the first half of the second century AD, this early Roman water infrastructure collapsed, cutting a vast part of the city (or at least Maloutena and the agora areas) off from water resources. To date, there is no evidence for a later restoration of this system, thus it appears that afterwards, the inhabitants returned to the water practices preceding the introduction of the aqueduct. This hypothesis raises, however, many questions. Has the early Roman waterworks actually not been rebuilt or simply not survived to the present day? In the first case, why? How would it be possible, that despite the limited water supply, the city began to develop so intensively, of which the most vivid proof was the erection of the VT with its bath complex and other water-consuming devices? These and many other questions should be addressed in further research.

Undertaken studies proved that although the fragmentary state of preservation of the pipelines, a closer examination may provide valuable conclusions on the water management system within the analysed area. It is, however, important to underline that results achieved to date should be treated as assumptions for further verification, whereas the methodology applied should be continuously tested and developed.

${ }^{105}$ Numerous Roman baths in Cyprus were supplied with water stored in cisterns, e.g. Public Baths on Acropolis and Baths of the House of the Gladiators in Kourion, Gymnasium Baths and Baths next to the Basilica of Campanopetra in Salamis or Baths in the HO in Paphos (see: Christodoulou 2014; see also Rekowska et al. 2021, in this volume).

${ }^{106}$ Meyza et al. 2011: 284, 289-290, Fig. 5.

107 Barker 2016. 


\section{Acknowledgements}

The presented study is a part of the author's $\mathrm{PhD}$ thesis research on the ancient water system of Maloutena. Documentation fieldworks were conducted in 2019 thanks to funds from the ZIP Programme (Integrated Development Programme) of the University of Warsaw, while further, substantive studies were possible thanks to the funds granted by the National Science Centre (Cracow, Poland) in the framework of the Preludium 16 programme (2018/31/N/HS3/03319).

\section{References}

Aupert, P. 2009: Amathonte hellénistique et impériale: l'apport des travaux récents, CCEC 39, 25-48

Balandier, C. 2017: Nea Paphos (Chypre). De la fondation hellénistique au développement de la ville romaine : derniers résultats de la Mission archéologique française à Paphos (MafaP) 2014-2017, DHA 43/2, 217-231

Balandier, C., Guintrand, M. 2016: Fabrika, un quartier résidentiel à Paphos? Résultats archéologiques et réflexion historique sur l'évolution urbaine du secteur Nord-Est de la ville antique, [in:] Balandier, C. (Ed.), Nea Paphos. Fondation et développement urbanistique d'une ville chypriote de l'Antiquité à nos jours. Études archéologiques, historiques et patrimoniales. Actes du $1^{\text {er }}$ colloque international sur Paphos, Avignon, 30, 31 octobre et $1^{\text {er }}$ novembre 2012, Ausonius Mémoires 34, Bordeaux, 121-143

Barker, C. 2007-2008: Excavations at the Site of the Hellenistic-Roman Theatre of Nea Paphos in Cyprus, 2007-2008, Australian Archaeological Institute at Athens Bulletin 5, 40-47

Barker, C. 2016: The Theatre Precinct of Nea Paphos (Fabrika): Recent Excavations by the Australian Mission, [in:] Balandier, C. (Ed.), Nea Paphos. Fondation et développement urbanistique d'une ville chypriote de l'Antiquité à nos jours. Études archéologiques, historiques et patrimoniales. Actes du $1^{\text {er }}$ colloque international sur Paphos, Avignon 30, 31 octobre et $1^{\text {er }}$ novembre 2012, Ausonius Mémoires 34, Bordeaux, 91-104

Bessac, J.-C. 2016: Les aspects techniques des aménagements rupestres de Paphos, [in:] Balandier, C. (Ed.), Nea Paphos. Fondation et développement urbanistique d'une ville chypriote de l'Antiquité à nos jours. Études archéologiques, historiques et patrimoniales. Actes du $1^{\text {er }}$ colloque international sur Paphos, Avignon 30, 31 octobre et $1^{\text {er }}$ novembre 2012, Ausonius Mémoires 34, Bordeaux, 105-120 Biernacka-Lubańska, M. 1973: Wodociągi rzymskie i wczesnobizantyjskie z obszaru Mezji Dolnej i północnej Tracji, Bibliotheca Antiqua 12, Wrocław

Brzozowska, A. 2016: A Pseudo-Ionic Blocked-out Capital at Nea Paphos, EtudTrav XXIX, 43-65

Christodoulou, S. 2014: Ancient Baths in Cyprus, [in:] Boussac, M.-Fr., Denoix, S., Fournet, Th., Redon, B. (Eds), 25 siècles de bain collectif en Orient: Proche-Orient, Égypte et péninsule Arabique: Balaneîa $=$ Thermae = Hamâmât : actes du $3^{\mathrm{e}}$ colloque international Balnéorient (Damas-Syrie / 2-6 nov. 2009), Le Caire, 83-106 
Christodoulou, S. 2015: Water Supply, Storage and Distribution during the Hellenistic and Roman Periods in Cyprus: Spatial and Social Considerations, [in:] Jacobs, A., Cosyns, P. (Eds), Cypriot material culture studies from picrolite carving to proskynitaria analysis. Proceedings of the 8th Annual Postgraduate Cypriot Archaeology Conference Held in Honour of the Memory of Paul Åström at the Vrije Universiteit Brussel (Belgium), 27th-29th November 2008, Brussels, 223-242

Christou, D. 1992: Chronique des fouilles et découvertes archéologiques à Chypre en 1991, BCH 116/2, 793-831

Christou, D. 1994: Chronique des fouilles et découvertes archéologiques à Chypre en 1993, BCH 118/2, 647-693

Crouch, D.P. 1984: The Hellenistic Water System of Morgantina, Sicily: Contributions to the History of Urbanization, AJA 88/3, 353-365

CyprusMail: https://cyprus-mail.com/2014/01/18/paphos-excavations-uncover-ancientbath-house/ (accessed September 20, 2021)

Daszewski, W.A. 1976: Les fouilles polonaises à Nea Paphos 1972-1975. Rapport préliminaire, RDAC 1976, 185-225

Daszewski, W.A. 1977: La mosaïque de Thésée. Études sur les mosaïques avec représentations du labyrinthe, de Thésée et du Minotaure, Nea Paphos II, Varsovie

Daszewski, W.A. 1991: Nea Paphos 1990 Report, PAM II, 78-84

Daszewski, W.A. 1994: Nea Paphos 1993, PAM V, 101-110

Daszewski, W.A. 1995: Nea Paphos 1994, PAM VI, 67-74

Daszewski, W.A. 1998: Nea Paphos 1965-1995, [in:] Daszewski, W.A., Meyza, H. (Eds), Cypr w badaniach polskich. Materiały z sesji naukowej zorganizowanej przez Centrum Archeologii Śródziemnomorskiej UW im. prof. K. Michałowskiego, Warszawa 24-25 luty 1995, Warszawa, 5-24

Daszewski, W.A. 2016: Une maison romaine construite à Nea Paphos (Maloutena) après le tremblement de terre de 15/14 a.C., [in:] Balandier, C. (Ed.), Nea Paphos. Fondation et développement urbanistique d'une ville chypriote de l'Antiquité à nos jours. Études archéologiques, historiques et patrimoniales. Actes du $1^{\mathrm{er}}$ colloque international sur Paphos, Avignon, 30, 31 octobre et $1^{\mathrm{er}}$ novembre 2012, Ausonius Mémoires 34, Bordeaux, 151-162

Daszewski, W.A., Meyza, H., Machowski, W., Papuci-Władyka, E., Rądkowska, J.K., Wasilewska, O. 2010: Nea Paphos. Season 2007, PAM XIX, 503-514

Daszewski, W.A., Michaelides, D. 1988: Guide to the Paphos Mosaics, Nicosia

Dobosz, A. 2020: Hellenistic and Roman Transport Amphorae, [in:] Papuci-Władyka, E. (Ed.), Interdisciplinary Research of the Jagiellonian University in Nea Paphos UNESCO World Heritage Site (2011-2015) - First Results, Paphos Agora Project 1, Cracow, 323-362

Forbes, R.J. 1964: Studies in Ancient Technology, vol. I, Leiden.

Green, J.R., Stennett, G. 2002: The architecture of the ancient theatre at Nea Pafos, RDAC 2002, 155-188

Hadjioannou, L. 1997: The Climate of Cyprus. Meteorological Service, Nicosia 
Hadjisavvas, S. 1977: The archaeological survey of Paphos. A preliminary report, $R D A C$ 1977, 222-231

Hadjistavrinou, Y., Afrodisis, S. 1977: Geology and Hydrogeology of the Paphos Region, Bulletin of the Geological Survey Department 7, 1-44

Hayes, J. 1977: Early Roman wares from the House of Dionysos, Paphos, RCRF 17/18, 96-108

Hodge, A.T. 1996: In Vitruvium Pompeianum. Urban Water Distribution Reappraised, AJA 100/2, 261-276

Hodge, A.T. 2000: Aqueducts, [in:] Wikander, Ö. (Ed.), Handbook of ancient water technology, Leiden-Boston-Köln, 39-65

Hodge, A.T. 2002: Roman aqueducts \& water supply, London

Jansen, G.C. 2000: Urban Water Transport and Distribution, [in:] Wikander, Ö. (Ed.), Handbook of ancient water technology, Leiden-Boston-Köln, 103-126

Jashemski, W.F. 1992: The gardens of Pompeii, Herculaneum and the villas destroyed by Vesuvius, The Journal of Garden History 12/2, 102-125

Juchniewicz, K.,Żuchowska, M. 2012: Water supply in Palmyra, a chronological approach, [in:] Żuchowska, M. (Ed.), The Archaeology of Water Supply, BAR-IS 2414, Oxford, 61-73

Juchniewicz, K., Żuchowska, M. 2013: Remarks on water supply in Palmyra. Results of a survey in 2010, PAM XXII, 341-350

Kalicki, T., Chwałek, S., Frączek, M. 2020: First Results of Geoarchaeological Studies on Site and off Site in Nea Paphos, [in:] Papuci-Władyka, E. (Ed.), Interdisciplinary Research of the Jagiellonian University in Nea Paphos UNESCO World Heritage Site (2011-2015) - First Results, Paphos Agora Project 1, Cracow, 487-502

Kambanellas, C.A. 2012: Historical development of water supply in Cyprus, [in:] Angelakis, A.N., Mays, L.W., Koutsoyiannis, D., Mamassis, N. (Eds), Evolution of Water Supply through the Millennia, London, 301-318

Kampanellas, Ch., Omorfos, Ch., Ioannou, Em., Fraghkescou, Th., Kokoti, V. 2003: Development of water resources in Cyprus - a historical review, s.l.

Karageorghis, V. 1985: Chronique des fouilles et découvertes archéologiques à Chypre en 1984, BCH 109/2, 897-967

Karageorghis, V. 1987: Chronique des fouilles et découvertes archéologiques à Chypre en 1986, BCH 111/2, 664-733

Karageorghis, V. 1988: Chronique des fouilles et découvertes archéologiques à Chypre en 1987, BCH 112/2, 793-855

Kessener, H.P. 2020: Byzantine water towers in the East: Palmyra and Apameia, AntTard 28, 127-137

Ktima 1955: Cyprus 1:50 000. Revised and printed by 42 Survey Engineer Regiment October 1955. GSGS 4242 (K.711) Sheet 2, $4^{\text {th }}$ Edition, s.l.

Landon, M.E. 1994: Contributions to the Study of the Water Supply of Ancient Corinth, unpublished $\mathrm{PhD}$ thesis, University of California, Berkeley

Last, J.S. 1975: Kourion: The Ancient Water Supply, Proceedings of the American Philosophical Society 119/1, 39-72 
Łajtar, A. 2021: A Weight of Seleucia in Pieria in Nea Paphos, EtudTrav XXXIV, 255-263 Malinowski, R. 1996: Dichtungsmörtel und Betone in der Antike, [in:] de Haan, N., Jansen, G.C.M. (Eds), Cura Aquarum in Campania. Proceedings of the Ninth International Congress on the History of Water Management and Hydraulic Engineering in the Mediterranean Region, BAB Suppl. 4, Leiden, 191-199

Martens, F. 2001: Urban water management at Sagalassos. Studying urban development from an hydrological perspective, [in:] Demoen, K. (Ed.), The Greek city from antiquity to the present: Historical reality, ideological construction, literary representation, Louvain-Paris-Sterling, 49-86

McCormick, M., Büntgen, U., Cane, M.A., Cook, E.R., Harper, K., Huybers, P., Litt, T., Manning, S.W., Mayewski, P.A., More, A.F.M., Nicolussi, K., Tegel, W. 2012: Climate Change during and after the Roman Empire: Reconstructing the Past from Scientific and Historical Evidence, Journal of Interdisciplinary History 43/2, 169-220

Medeksza, S. 1992: Willa Tezeusza w Nea Pafos. Rezydencja antyczna, Prace Naukowe Instytutu Historii Architektury, Sztuki i Techniki Politechniki Wrocławskiej 27, Monografie 15, Wrocław

Medeksza, S. 1998: Willa Tezeusza w Nea Pafos na Cyprze: powstanie i fazy rozwoju, [in:] Daszewski, W.A., Meyza, H. (Eds), Cypr w badaniach polskich. Materiały z sesji naukowej zorganizowanej przez Centrum Archeologii Śródziemnomorskiej UW im. prof. K. Michałowskiego, Warszawa, 24-25 luty 1995, Warszawa, 25-50

Meyza, H., Daszewski, W.A., Brzozowska, A., Michalska, J., Rądkowska, J.K., Więch, M. 2012: Nea Paphos. Season 2009, PAM XXI, 407-422

Meyza, H., Daszewski, W.A., Zarzycka, M., Michalska-Bartoszek, J., Papuci-Władyka, E., Wasilewska, O., Więch, M. 2011: Nea Paphos. Season 2008, PAM XX, 283-294

Meyza, H., Romaniuk, M., Więch, M. with appendices by Mazanek-Somerlik, D., Więch, M. 2017: Nea Paphos. Seasons 2014 and 2016, PAM XXVI/1, 399-428

Miszk, Ł. 2020: Stratigraphy and Architecture of the Agora, [in:] Papuci-Władyka, E. (Ed.), Interdisciplinary Research of the Jagiellonian University in Nea Paphos UNESCO World Heritage Site (2011-2015) - First Results, Paphos Agora Project 1, Cracow, 127-184

Mitford, T.B. 1950: New Inscriptions from Roman Cyprus, OpArch 6, 1-95

Mitford, T.B. 1971: The inscriptions of Kourion, Philadelphia

Mitford, T.B. 1980: Roman Cyprus, [in:] Temporini, H. (Ed.), Aufstieg und Niedergang der römischen Welt. Band 7/2. Halbband: Politische Geschichte (Provinzen und Randvölker: Griechischer Balkanraum; Kleinasien [Forts]), Berlin-New York, 1285-1384

Młynarczyk, J. 1985: Remarks on the Town Plan of Hellenistic Nea Paphos, [in:] Papadopoulos, T., Hadjistylis, S.A. (Eds), Acts of the Second International Congress of Cypriot Studies, 20-25 April 1982, Nicosia, 317-325

Młynarczyk, J. 1990: Nea Paphos in the Hellenistic Period, Nea Paphos III, Varsovie

Młynarczyk, J. 1996: Palaces of strategoi and the Ptolemies in Nea Paphos. Topographical remarks, [in:] Hoepfner, W., Brands, G. (Eds), Basileia. Die Paläste der hellenisti- 
schen Könige. Internationales Symposion in Berlin vom 16.12.1992 bis 20.12.1992, Mainz a/Rhein, 193-202

Młynarczyk, J. 2016: Walking around the Site of Nea Paphos and through the Decades of its Exploration, [in:] Balandier, C. (Ed.), Nea Paphos. Fondation et développement urbanistique d'une ville chypriote de l'Antiquité à nos jours. Études archéologiques, historiques et patrimoniales. Actes du $1^{\text {er }}$ colloque international sur Paphos, Avignon 30, 31 octobre et $1^{\text {er }}$ novembre 2012, Ausonius Mémoires 34, Bordeaux, 33-46

Nicolaou, K. 1963: Inscriptiones Cypriae Alphabeticae (II) 1962, RDAC 1963, 41-51

Nicolaou, K. 1966: The Topography of Nea Paphos, [in:] Bernhard, M.L. (Ed.), Mélanges offerts à Kazimierz Michałowski, Warszawa, 561-601

Ostrowski, W., Miszk, Ł., Winiarska, W., Hanus, K. 2020: Low Altitude (UAV) Photogrammetry and Remote Sensing, [in:] Papuci-Władyka, E. (Ed.), Interdisciplinary Research of the Jagiellonian University in Nea Paphos UNESCO World Heritage Site (2011-2015) - First Results, Paphos Agora Project 1, Cracow, 475-485

Palinkas, J., Herbst, J.A. 2011: A Roman road southeast of the forum at Corinth: Technology and urban development, Hesperia 80/2, 287-336

Papageorghiou, A. 1990: Chronique des fouilles et découvertes archéologiques à Chypre en 1989, BCH 114/2, 941-985

Papuci-Władyka, E. 2020: Paphos Agora Project (PAP): its Aims, Stages of Development, Methodology and Chronology, [in:] Papuci-Władyka, E. (Ed.), Interdisciplinary Research of the Jagiellonian University in Nea Paphos UNESCO World Heritage Site (2011-2015) - First Results, Paphos Agora Project 1, Cracow, 73-89

Peristianis, I.K. 1927: He Nea Paphos. Dialeksis genome epi ton ereipion tes Neas Paphou 4.10.1926, Kypriaka Chronika V, 24-43

Pickett, J. 2016: Temples, churches, cisterns and pipes: Water in late antique Ephesus, [in:] Wiplinger, G. (Ed.), De Aquaeductu Atque Aqua Urbium Lyciae Pamphyliae Pisidiae: The Legacy of Sextus Julius Frontinus. Tagungsband des Internationalen Frontinus-Symposiums. Antalya, 31. Oktober-9. November 2014, BAB Suppl. 27, Leuven, 297-312

Raptou, E. 2016: La périphérie de Nea Paphos aux périodes hellénistique et romaine [in:] Balandier, C. (Ed.), Nea Paphos. Fondation et développement urbanistique d'une ville chypriote de l'Antiquité à nos jours. Études archéologiques, historiques et patrimoniales. Actes du $1^{\text {er }}$ colloque international sur Paphos, Avignon 30, 31 octobre et $1^{\text {er }}$ novembre 2012, Ausonius Mémoires 34, Bordeaux, 47-65

Rekowska, M., Michaelides, D., Christodoulou, S., Kaniszewski, J. 2021: Adopting Roman Habits - The Baths in the House of Orpheus in Nea Paphos as a 'Troublesome' Case Study?, EtudTrav XXXIV, 341-362

Roman aqueducts: http://www.romanaqueducts.info/aquasite/amathus/index.html (accessed January 22, 2021)

Romaniuk, M.M. 2017: A circular pool in the main courtyard of the "Hellenistic" House in Nea Paphos. Preliminary remarks, PAM XXVI/1, 429-440 
Rosińska-Balik, K. 2020: An Overview of the Architectural Features of the Agora, [in:] Papuci-Władyka, E. (Ed.), Interdisciplinary Research of the Jagiellonian University in Nea Paphos UNESCO World Heritage Site (2011-2015) - First Results, Paphos Agora Project 1, Cracow, 185-214

Sanders, G.D.R. 1999: A Late Roman Bath at Corinth: Excavations in the Panayia Field, 1995-1996, Hesperia 68/4, 441-480

Sparrow, D.J., John, E. 2016: An introduction to the wildlife of Cyprus, Limassol

Sürmelihindi, G., Passchier, C.W. 2013: Sinter analysis - a tool for the study of ancient aqueducts, [in:] Wiplinger, G. (Ed.), Historische Wasserleitungen Gestern-HeuteMorgen. Tagungsband des Internationalen Frontinus-Symposiums Wien, 19.-23. Oktober 2011, BAB Suppl. 24, Leuven-Walpole, MA., 269-287

Wellbrock, K. 2012: Tonrohre der innerstädtischen Wasserversorgung von Pergamon - Überlegungen zur Katalogisierung und Typologie, [in:] Ohlig, Ch. (Ed.) Zehn Jahre wasserhistorische Forschungen und Berichte, Schriften der Deutschen Wasserhistorischen Gesellschaft 20/1, 123-144

Wiegand, Th., Schrader, H. 1904: Priene. Ergebnisse der Ausgrabungen und Untersuchungen in den Jahren 1895-1898, Berlin

Wilson, A.I. 2008: Hydraulic engineering and water supply, [in:] Oleson, J.P. (Ed.) The Oxford Handbook of Engineering and Technology in the Classical World, New York, 285-318 
Table 1. Morphological characteristics of pipe types discussed in the article

\begin{tabular}{|c|c|c|}
\hline Type & Shape & Fabric \\
\hline 1 & $\begin{array}{l}\text { M/F form, hourglass body, helically ridged; M: flange slightly flared inwardly, thickened toward } \\
\text { the horizontally flat lip of rounded edges, with the rounded shoulder; F: flange flaring outwardly } \\
\text { from a pinched up stop, thickened to the horizontally flat lip of rounded edges }\end{array}$ & 1 \\
\hline 2 & $\begin{array}{l}\text { M/F form, hourglass body, helically ridged; M: flange slightly flared inwardly, thickened toward } \\
\text { the horizontally flat lip of rounded edges, with the rounded shoulder; F: flange flaring outwardly } \\
\text { from a pinched up stop, thickened to the horizontally flat lip of rounded edges }\end{array}$ & 2,3 \\
\hline 3 & $\begin{array}{l}\text { M/F form, hourglass body, helically ridged; M: cylindrical flange slightly thickened to the } \\
\text { horizontally flat lip of slightly rounded edges; F: flange flaring outwardly from a pinched up } \\
\text { stop, thickened to the horizontally flat lip of slightly rounded edges }\end{array}$ & 4 \\
\hline 4 & $\begin{array}{l}\text { M/F form, hourglass body, smooth/slightly undulating surface, occ. shallow ridges; M: cylindrical } \\
\text { flange slightly flared inwardly, thickened toward the horizontally flat lip, rounded on the edges, } \\
\text { with sharp/ rounded shoulder occ. accentuated on the body; F: flange flaring outwardly from } \\
\text { a pinched up stop, thickened to the horizontally flat lip of slightly rounded edges }\end{array}$ & 5 \\
\hline 5 & $\begin{array}{l}\text { M/F form, elongated, hourglass body, smooth surface; M: flange slightly flared inwardly, } \\
\text { thickened toward the horizontally flat lip, rounded on the edges, with sharp/rounded shoulder } \\
\text { occ. accentuated on the body; F: flange flaring outwardly from a built-up stop, thickened to the } \\
\text { horizontally flat lip of slightly rounded on the edges }\end{array}$ & 6 \\
\hline 6 & $\begin{array}{l}\text { M/F form, body slightly concave at the ends and belled in the middle (walls thickened here up } \\
\text { to } 3 \mathrm{~cm} \text { ), smooth, occ. undulating surface; M: flange flared inwardly, thickened to the rounded } \\
\text { lips, with the sharp shoulder; F: flange flaring outwardly from a pinched up stop, thickened to } \\
\text { the horizontally flat lip of rather sharp edges }\end{array}$ & 7 \\
\hline 7 & $\begin{array}{l}\text { (only one end preserved) thickened rim, body belled at the end and narrowed, cylindrical, } \\
\text { helically ridged in the middle }\end{array}$ & 3 \\
\hline 8 & $\begin{array}{l}\text { M/F form, body slightly widened at the } \mathrm{M} \text {, undulating surface; M: flange strongly concave } \\
\text { inwardly, smoothly transformed from the rounded shoulder, thickened to the horizontally flat } \\
\text { lip rounded on the edges; F: flange slightly flaring outwardly from a modest pinched-up stop, } \\
\text { slightly thickened to the horizontally flat lip of rounded edges }\end{array}$ & 3 \\
\hline
\end{tabular}

M/F - abbreviation for spigot-socket (male end/female end) form of a pipe. 
Table 2. Measurements of pipes representing particular types discussed in the article

\begin{tabular}{|c|c|c|c|c|c|c|c|c|}
\hline \multirow[b]{2}{*}{ 岂 } & \multirow[b]{2}{*}{ 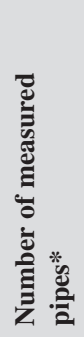 } & \multicolumn{3}{|c|}{ Body dimensions (cm) } & \multicolumn{2}{|c|}{$\begin{array}{c}\text { Male end } \\
\text { dimensions }(\mathrm{cm})\end{array}$} & \multicolumn{2}{|c|}{$\begin{array}{c}\text { Female end } \\
\text { dimensions }(\mathrm{cm})\end{array}$} \\
\hline & & $\begin{array}{l}\text { 总 } \\
\text { 巳一 }\end{array}$ & 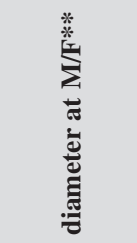 & 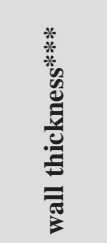 & 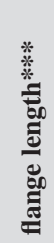 & 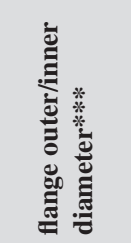 & 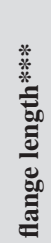 & 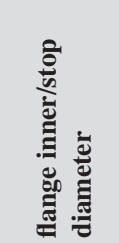 \\
\hline 1 & 16 & 31.3-33.6 & $\begin{array}{l}14.2-15.2 \\
/ 14.7-15.3\end{array}$ & $1.2-1.5$ & 3.4 & $10.0 / 8.40$ & 3.4 & $10.5 / 10.5$ \\
\hline 2 & 21 & $32.5-40$ & $\begin{array}{l}18.2-19.2 \\
/ 18-20.5\end{array}$ & $1.2-1.7$ & 2.7 & $13.0 / 10.4$ & 4.2 & $13.0 / 12.8$ \\
\hline 3 & 17 & $26.0-31.8$ & $\begin{array}{c}17.5-19 \\
/ 17.9-18.9\end{array}$ & $1.7-2.1$ & 4.0 & 13.8/11.8 & 3.9 & $15.0 / 14.0$ \\
\hline 4 & 6 & $35.0-38.5$ & $\begin{array}{l}15.1-16.5 \\
/ 15.2-16.5\end{array}$ & $1.3-1.9$ & 2.8 & $9.5 / 7.4$ & 3.8 & $11.6 / 11.0$ \\
\hline 5 & 4 & $40.0-44.5$ & $\begin{array}{l}16.2-17.6 \\
/ 15.8-16.9\end{array}$ & $1.2-2.0$ & 3.0 & $12.4 / 10.4$ & 3 & $12.8 / 11.7$ \\
\hline 6 & 2 & $35.8-36.5$ & $\begin{array}{l}15.6-17.2 \\
/ 15.7-17.4\end{array}$ & $1.3-2.6$ & 3.0 & $11.4 / 8.8$ & 2.9 & $12.6 / 11.5$ \\
\hline 7 & 1 & $>49.1$ & 15.3 & $1.0-1.7$ & - & $-/ 11.7$ & - & - \\
\hline 8 & 1 & 27.7 & $14.8 / 14.2$ & $1.0-1.4$ & 2.2 & $10.8 / 8.9$ & 2.5 & $12.0 / 11.4$ \\
\hline
\end{tabular}

* given measurements are based on the pipes that were preserved sufficiently to measure their full body length and diameter (excluding the pipe of type 7).

** $\mathrm{M} / \mathrm{F}$ - abbreviation for male end/female end; in case of pipe type 7 it relates to the only preserved end, of thickened-rim type.

*** the presented dimensions were taken from the cross-sections pictured in Fig. 3 to illustrate approximate value, as these were available to measure in the field only in the single cases; in case of pipe type 7 only inner diameter of the only preserved end, of thickened-rim type, is given. 
Table 3. Catalogue of the fabrics of pipes discussed in the article

\begin{tabular}{|c|c|c|c|c|c|c|}
\hline 苋 & $\frac{\Xi}{0}$ & 竞 & 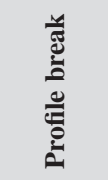 & 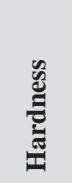 & 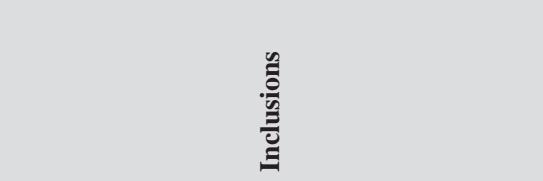 & 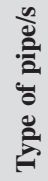 \\
\hline 1 & $\begin{array}{l}\text { core: 5YR6/8; } \\
\text { surface: 5YR7/4 }\end{array}$ & harsh & hackly & hard & $\begin{array}{l}\text { common medium to large (occ. very large) spher- } \\
\text { ical (occ. tabular) angular (occ. subrounded) } \\
\text { brown, dark red, dark grey inclusions; rare small } \\
\text { to medium spherical round white (empty inside } \\
\text { or of cellular structure) inclusions }\end{array}$ & 1 \\
\hline 2 & $\begin{array}{l}\text { core: 5YR7/6; } \\
\text { surface: 2.5YR7/4 }\end{array}$ & harsh & hackly & hard & $\begin{array}{l}\text { common medium to very large spherical angular } \\
\text { to rounded white, pale grey, dark grey, dark brown } \\
\text { and dark red inclusions; rare small to medium } \\
\text { spherical round white (empty inside or of cellular } \\
\text { structure) inclusions }\end{array}$ & 2 \\
\hline 3 & $\begin{array}{l}\text { core: } 2.5 \text { YR5/6; } \\
\text { surface: } 10 \mathrm{R} 7 / 4 \text {, } \\
\text { 10R6/6, } 7.5 \text { YR7/3 }\end{array}$ & harsh & hackly & hard & $\begin{array}{l}\text { abundant medium to very large spherical and } \\
\text { tabular angular (occ. subrounded) dark brown } \\
\text { and dark red inclusions; rare small to medium } \\
\text { spherical subrounded dark red and white inclu- } \\
\text { sions; rare small spherical round white inclusions }\end{array}$ & $\begin{array}{l}2, \\
7 \\
8\end{array}$ \\
\hline 4 & $\begin{array}{l}\text { core: 7.5YR5/6; } \\
\text { surface: 5YR5/4 }\end{array}$ & $\begin{array}{l}\text { harsh/ } \\
\text { rough }\end{array}$ & $\begin{array}{l}\text { hackly/ } \\
\text { granular }\end{array}$ & hard & $\begin{array}{l}\text { abundant fine to medium (occ. to very large) } \\
\text { spherical subrounded and angular dark grey, light } \\
\text { grey and occ. white and red inclusions }\end{array}$ & 3 \\
\hline 5 & $\begin{array}{l}\text { core: } 7.5 \text { YR6/3, } \\
\text { 10YR6/3; } \\
\text { surface: } \\
7.5 Y R \text { 6/4 }\end{array}$ & $\begin{array}{l}\text { harsh/ } \\
\text { rough }\end{array}$ & $\begin{array}{l}\text { hackly/ } \\
\text { granular }\end{array}$ & hard & $\begin{array}{l}\text { common small to medium (occ. large to very } \\
\text { large) spherical angular and subrounded dark } \\
\text { grey, dark brown and dark red inclusions }\end{array}$ & 4 \\
\hline 6 & 5YR6/6 & rough & hackly & hard & $\begin{array}{l}\text { frequent small to medium (occ. large) spherical } \\
\text { angular and subrounded pale brown and brown } \\
\text { inclusions; common fine and small spherical } \\
\text { rounded white inclusions; rare of white round } \\
\text { inclusions of cellular structure }\end{array}$ & 5 \\
\hline 7 & $\begin{array}{l}\text { core: 5YR3/4; } \\
\text { surface: 7.5YR6/2 }\end{array}$ & harsh & $\begin{array}{l}\text { hackly/ } \\
\text { granular }\end{array}$ & hard & $\begin{array}{l}\text { abundant medium to very large spherical and } \\
\text { tabular angular and subrounded, white, pale } \\
\text { brown, dark brown, grey and red inclusions }\end{array}$ & 6 \\
\hline
\end{tabular}


Table 4. Catalogue of terracotta pipelines discussed in the article

\begin{tabular}{|c|c|c|c|c|c|c|c|c|}
\hline 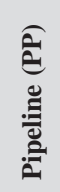 & 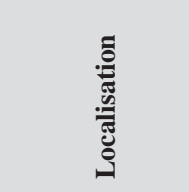 & 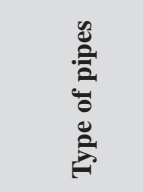 & 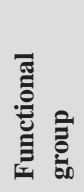 & 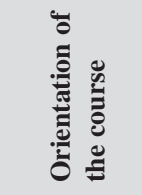 & 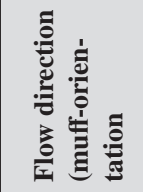 & 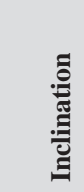 & 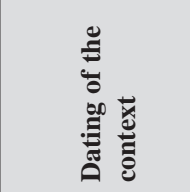 & 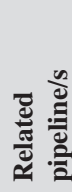 \\
\hline 1 & $\begin{array}{l}\text { Street A' } \\
\text { (south of RH) }\end{array}$ & 2 & I & $\begin{array}{l}\text { horizontal, } \\
\text { E-W }\end{array}$ & W & $\mathrm{W}$ & $\begin{array}{l}\text { mid-first-mid- } \\
\text { second century } \\
\text { AD }\end{array}$ & $4 ?$ \\
\hline 2 & $\begin{array}{l}\text { Street A' } \\
\text { (south of } \\
\text { RH9,9W) }\end{array}$ & $\begin{array}{l}\text { a variant } \\
\text { of type } 2 \text { ? } \\
\text { (same as in } \\
\text { PP3 } \\
\text { and PP6) }\end{array}$ & I & $\begin{array}{l}\text { horizontal, } \\
\text { E-W }\end{array}$ & E & $\mathrm{E}$ & as above & $\begin{array}{l}2.1 \\
3 ?\end{array}$ \\
\hline 2.1 & $\begin{array}{l}\text { Street A' } \\
\text { (south of RH9) }\end{array}$ & $2 ?$ & II & vertical & downward & $\mathrm{S}$ & as above & 2 \\
\hline 3 & $\begin{array}{l}\text { Street A' } \\
\text { (south of HH3) }\end{array}$ & $\begin{array}{l}\text { a variant } \\
\text { of type } 2 \text { ? } \\
\text { (same as in } \\
\text { PP2 } \\
\text { and PP6) }\end{array}$ & I & $\begin{array}{l}\text { horizontal, } \\
\text { E-W }\end{array}$ & E & E & as above & 2? 6? \\
\hline 4 & as above & type 2 & I & $\begin{array}{l}\text { horizontal, } \\
\text { E-W }\end{array}$ & W & $\mathrm{W}$ & as above & 1 ? \\
\hline 5 & as above & - & I & $\begin{array}{l}\text { horizontal, } \\
\text { E-W }\end{array}$ & - & - & as above & - \\
\hline 6 & Street A'/HH3 & $\begin{array}{l}\text { a variant } \\
\text { of type } 2 \text { ? } \\
\text { (same as } \\
\text { in PP2 } \\
\text { and PP3) }\end{array}$ & II & $\begin{array}{l}\text { horizontal, } \\
\text { N-S }\end{array}$ & $\mathrm{N}$ & $\mathrm{N}$ & as above & $3 ?$ \\
\hline 7 & HH3 & 1 & III & $\begin{array}{l}\text { horizontal, } \\
\text { E-W }\end{array}$ & E & - & as above & $\begin{array}{c}8 ? 9 ? \\
10 ?\end{array}$ \\
\hline 8 & НН3/4 & 1 ? & III & $\begin{array}{l}\text { horizontal, } \\
\text { NW-SE }\end{array}$ & - & - & ? & $\begin{array}{c}\text { 7? 9? } \\
10 ?\end{array}$ \\
\hline 9 & $\mathrm{HH} 29 / 4$ & 1 ? & III & $\begin{array}{l}\text { horizontal, } \\
\text { NW-SE }\end{array}$ & - & - & ? & $\begin{array}{c}\text { 7? 8? } \\
10 ?\end{array}$ \\
\hline 10 & HH29 & 1 & III & $\begin{array}{l}\text { horizontal, } \\
\text { E-W }\end{array}$ & E & - & $\begin{array}{l}\text { mid-first-mid- } \\
\text { second century } \\
\text { AD }\end{array}$ & $\begin{array}{c}\text { 7? 8? } \\
9 ?\end{array}$ \\
\hline 11 & HH13 & $\begin{array}{l}\text { a variant } \\
\text { of type } 2 \text { ? }\end{array}$ & III & $\begin{array}{l}\text { horizontal, } \\
\text { E-W }\end{array}$ & E & $\mathrm{E}$ & as above & - \\
\hline 12 & Street 10/HH32 & 2 & II & $\begin{array}{l}\text { horizontal, } \\
\text { later } \\
\text { vertical, } \\
\text { E-W }\end{array}$ & $\begin{array}{l}\text { E, later } \\
\text { upward }\end{array}$ & W & as above & - \\
\hline
\end{tabular}




\begin{tabular}{|c|c|c|c|c|c|c|c|c|}
\hline 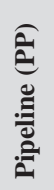 & 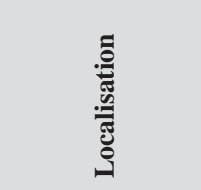 & 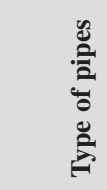 & 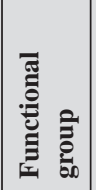 & 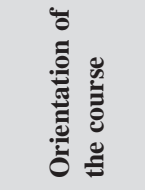 & 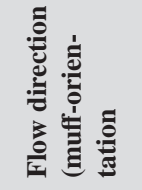 & 氖 & 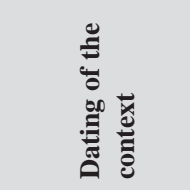 & 递蓠 \\
\hline 13 & HH13 & - & III & vertical & downward & - & $\begin{array}{l}\text { before mid- } \\
\text { second century } \\
\mathrm{AD}\end{array}$ & - \\
\hline 14 & HH1 & - & III & $\begin{array}{l}\text { horizontal, } \\
\text { N-S }\end{array}$ & $\mathrm{N}$ & - & as above & - \\
\hline 15 & HH2 & type 1 ? & III & $\begin{array}{l}\text { horizontal, } \\
\text { N-S }\end{array}$ & $\mathrm{N}$ ? & - & $\begin{array}{l}\text { mid-first-mid- } \\
\text { second century } \\
\text { AD }\end{array}$ & - \\
\hline 16 & as above & - & III & vertical & downward & - & as above & - \\
\hline 17 & HH3 & - & III & $\begin{array}{l}\text { horizontal, } \\
\text { E-W }\end{array}$ & - & - & $\begin{array}{l}\text { second/first } \\
\text { century BC }\end{array}$ & - \\
\hline 18 & as above & - & III & $\begin{array}{l}\text { horizontal, } \\
\text { NW-SE }\end{array}$ & - & - & as above & - \\
\hline 19 & as above & - & III & $\begin{array}{l}\text { horizontal, } \\
\text { N-S }\end{array}$ & - & - & as above & - \\
\hline 20 & $\begin{array}{l}\text { Street A } \\
\text { (west of VT32) }\end{array}$ & - & II & $\begin{array}{l}\text { horizontal, } \\
\text { NW-SE }\end{array}$ & - & - & ? & - \\
\hline 21 & as above & - & II & $\begin{array}{l}\text { horizontal, } \\
\text { NW-SE }\end{array}$ & - & - & ? & - \\
\hline 22 & $\begin{array}{l}\text { Street A } \\
\text { (VT38) }\end{array}$ & 4 & I & $\begin{array}{l}\text { horizontal, } \\
\text { E-W }\end{array}$ & - & constant & $\begin{array}{l}\text { mid-first-mid- } \\
\text { second century } \\
\text { AD }\end{array}$ & - \\
\hline 23 & $\begin{array}{l}\text { Street } 9 \\
\text { (south of VT63) }\end{array}$ & $4 ?$ & II & $\begin{array}{l}\text { horizontal, } \\
\text { E-W }\end{array}$ & - & constant & as above & - \\
\hline 24 & $\begin{array}{l}\text { Street } 9 \\
\text { (unexcavated } \\
\text { building to the } \\
\text { east, south of } \\
\text { VT63) }\end{array}$ & 5 & II & $\begin{array}{l}\text { horizontal, } \\
\text { NW-SE }\end{array}$ & - & constant & as above & - \\
\hline 25 & VT64 & - & III & $\begin{array}{l}\text { vertical, } \\
\text { later hori- } \\
\text { zontal, } \\
\text { E-W }\end{array}$ & $\begin{array}{l}\text { downward, } \\
\text { later E }\end{array}$ & $\begin{array}{l}\text { vertical, } \\
\text { later hori- } \\
\text { zontal, } \\
\text { constant }\end{array}$ & $\begin{array}{l}\text { after the fourth } \\
\text { century AD } \\
\text { (second phase } \\
\text { of VT) }\end{array}$ & $27 ?$ \\
\hline 26 & VT64 & - & III & vertical & downward & vertical & as above & $27 ?$ \\
\hline 27 & VT67 & - & III & $\begin{array}{l}\text { horizontal, } \\
\text { SW-NE }\end{array}$ & $\mathrm{NE}$ & NE? & as above & $\begin{array}{l}25 ? \\
26 ?\end{array}$ \\
\hline 28 & $\begin{array}{l}\text { VT60 } \\
\text { (in the north } \\
\text { wall) }\end{array}$ & 8 & III & $\begin{array}{l}\text { horizontal, } \\
\text { E-W }\end{array}$ & $\begin{array}{l}\mathrm{E} \text { (in the } \\
\text { wall) }\end{array}$ & constant & as above & - \\
\hline
\end{tabular}




\begin{tabular}{|c|c|c|c|c|c|c|c|c|}
\hline 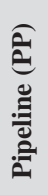 & 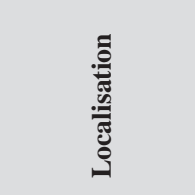 & 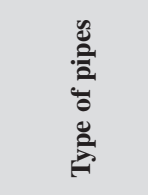 & 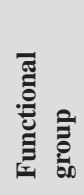 & 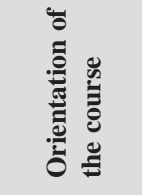 & 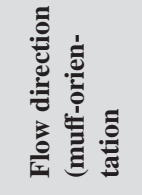 & .气 & 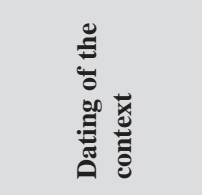 & 总 \\
\hline 29 & $\begin{array}{l}\text { VT60 } \\
\text { (in the east } \\
\text { wall) }\end{array}$ & - & III & $\begin{array}{l}\text { vertical, } \\
\text { later hori- } \\
\text { zontal, N-S }\end{array}$ & $\begin{array}{l}\text { downward, } \\
\text { later S (in } \\
\text { the wall) }\end{array}$ & $\begin{array}{l}\text { vertical, } \\
\text { later hori- } \\
\text { zontal } \\
\text { to S }\end{array}$ & as above & - \\
\hline 30 & VT45 & - & III & $\begin{array}{l}\text { horizontal, } \\
\text { N-S }\end{array}$ & - & - & $\begin{array}{l}\text { after the second } \\
\text { century AD } \\
\text { (after the first } \\
\text { phase of VT) }\end{array}$ & - \\
\hline 31 & $\begin{array}{l}\text { Street } 9 \\
\text { (VT36) }\end{array}$ & 2 & I & $\begin{array}{l}\text { horizontal, } \\
\text { N-S }\end{array}$ & S & - & $\begin{array}{l}\text { mid-first-mid- } \\
\text { second century } \\
\text { AD }\end{array}$ & $32 ?$ \\
\hline 32 & $\begin{array}{l}\text { Street } 9 \\
\text { (VT82) }\end{array}$ & 2 & I & $\begin{array}{l}\text { horizontal, } \\
\text { N-S }\end{array}$ & $\mathrm{S}$ & - & as above & $31 ?$ \\
\hline 33 & $\begin{array}{l}\text { Street } 9 \\
\text { (VT98) }\end{array}$ & - & I & $\begin{array}{l}\text { horizontal, } \\
\text { N-S }\end{array}$ & $\mathrm{S}$ & - & $\begin{array}{l}\text { before fourth } \\
\text { century AD? } \\
\text { (before the } \\
\text { second phase } \\
\text { of VT) }\end{array}$ & - \\
\hline 34 & $\begin{array}{l}\text { Street B } \\
\text { (central court- } \\
\text { yard of VT) }\end{array}$ & $\begin{array}{l}\text { a variant } \\
\text { of type } 2 \text { ? } \\
\text { (same as in } \\
\text { PP35?) }\end{array}$ & I & $\begin{array}{l}\text { horizontal, } \\
\text { E-W }\end{array}$ & W? & W? & $\begin{array}{l}\text { second/third } \\
\text { century AD or } \\
\text { earlier }\end{array}$ & $35 ?$ \\
\hline 35 & as above & $\begin{array}{l}\text { a variant } \\
\text { of type } 2 \text { ? } \\
\text { (same as in } \\
\text { PP34?) }\end{array}$ & I & $\begin{array}{l}\text { horizontal, } \\
\text { E-W }\end{array}$ & W? & W? & as above & $34 ?$ \\
\hline 36 & $\begin{array}{l}\text { Late Roman } \\
\text { Street/Street B }\end{array}$ & - & II & vertical & downward & vertical & $\begin{array}{l}\text { after the fourth } \\
\text { century AD } \\
\text { (after the second } \\
\text { phase of VT) }\end{array}$ & - \\
\hline 37 & as above & - & II & $\begin{array}{l}\text { horizontal, } \\
\text { NW-SE }\end{array}$ & E, later SE & SE & as above & - \\
\hline 38 & $\begin{array}{l}\text { VT/Late Roman } \\
\text { Street }\end{array}$ & - & II & $\begin{array}{l}\text { horizontal, } \\
\text { E-W }\end{array}$ & - & - & ? & - \\
\hline 39 & HA1 & $\begin{array}{l}6 \text { joint with } \\
\text { unclassified }\end{array}$ & III & $\begin{array}{l}\text { horizontal, } \\
\text { N-S, later } \\
\text { E-W }\end{array}$ & $\mathrm{S}$, later $\mathrm{E}$ & $\begin{array}{l}\text { S, later } \\
\mathrm{E}\end{array}$ & $\begin{array}{l}\text { before fourth } \\
\text { century AD }\end{array}$ & - \\
\hline 40 & $\begin{array}{l}\text { Street B } \\
\text { (south of HA) }\end{array}$ & 3 & I & $\begin{array}{l}\text { horizontal, } \\
\text { E-W }\end{array}$ & W & W & $\begin{array}{l}\text { second-fourth } \\
\text { century AD? }\end{array}$ & - \\
\hline
\end{tabular}




\begin{tabular}{|c|c|c|c|c|c|c|c|c|}
\hline 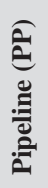 & 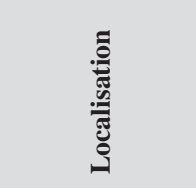 & 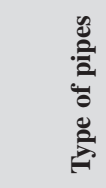 & 를 을 & 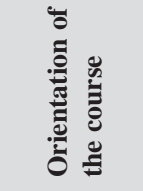 & 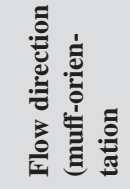 & .0્己 & 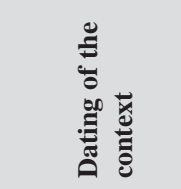 & 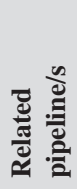 \\
\hline 41 & $\begin{array}{l}\text { Street } 9 \\
\text { (west of } \\
\text { VT97SW) }\end{array}$ & - & II & $\begin{array}{l}\text { horizontal, } \\
\text { E-W }\end{array}$ & $\mathrm{E}$ & $\mathrm{E}$ & ? & - \\
\hline 42 & as above & 4 & I & $\begin{array}{l}\text { horizontal, } \\
\text { N-S }\end{array}$ & $\mathrm{S}$ & S & $\begin{array}{l}\text { mid-first-mid- } \\
\text { second century } \\
\text { AD or earlier }\end{array}$ & $43 ?$ \\
\hline 43 & Street 9/Street C & 4 & I & $\begin{array}{l}\text { horizontal, } \\
\text { N-S }\end{array}$ & S & S & as above & $42 ?$ \\
\hline 44 & $\begin{array}{l}\text { Street C } \\
\text { (north of } \\
\text { VT13E2) }\end{array}$ & - & I & $\begin{array}{l}\text { horizontal, } \\
\text { E-W }\end{array}$ & - & - & ? & - \\
\hline 45 & $\begin{array}{l}\text { VT59 } \\
\text { (in the north } \\
\text { wall) }\end{array}$ & - & III & $\begin{array}{l}\text { horizontal, } \\
\text { E-W }\end{array}$ & - & - & $\begin{array}{l}\text { after the fourth } \\
\text { century AD } \\
\text { (second phase } \\
\text { of VT) }\end{array}$ & - \\
\hline 46 & HH1 & 7 & III & horizontal? & - & - & $\begin{array}{l}\text { before mid- } \\
\text { second } \\
\text { century AD }\end{array}$ & - \\
\hline
\end{tabular}

- unclassified within the column 'Type of pipes'; undeterminable in the cases of the columns 'Flow direction' and 'Inclination'. 


\section{ÉTUDES et TRAVAUX XXXIV / 2021}
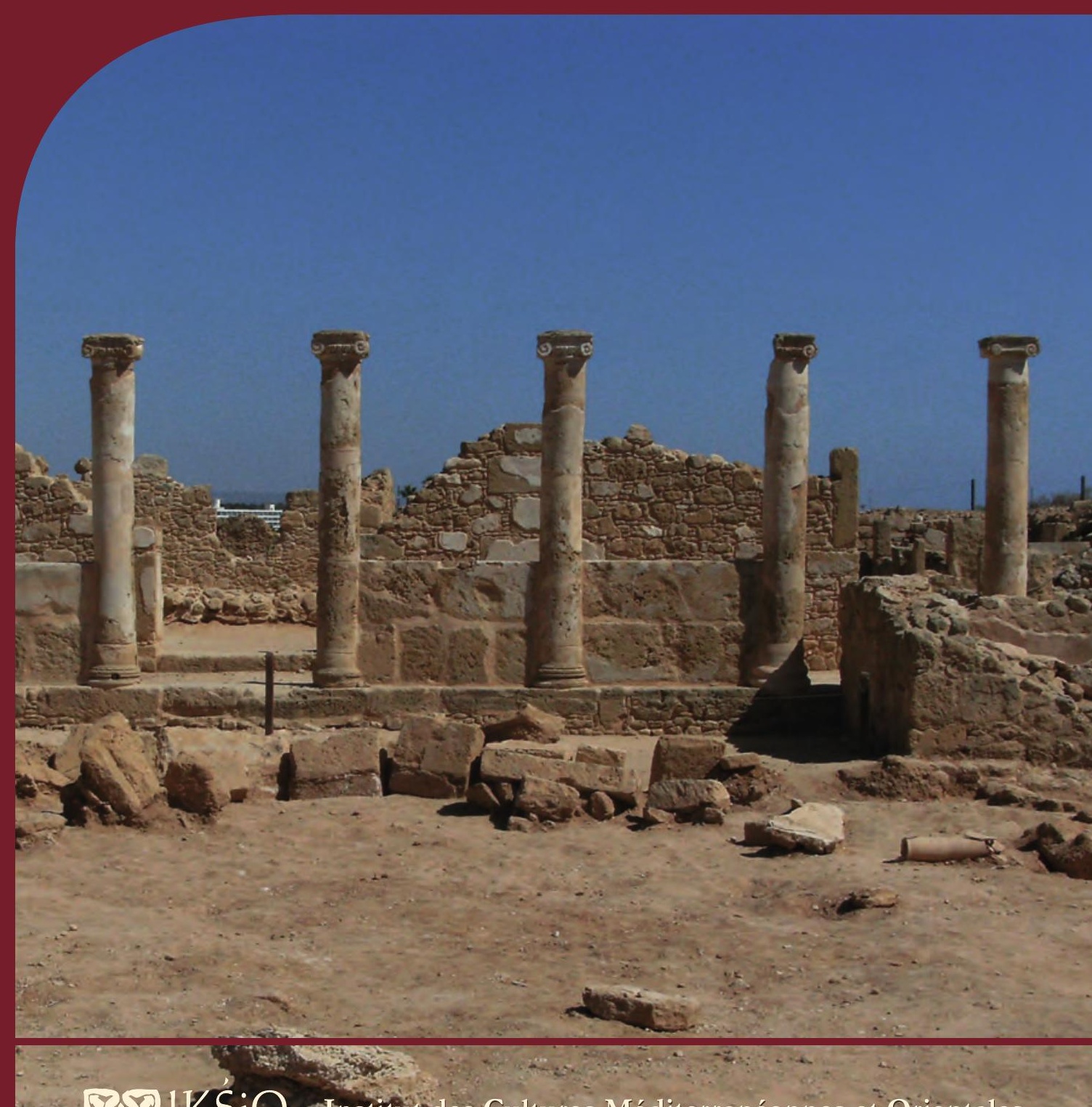

W $92 \mathrm{HKSiO}$ Institut des Cultures Méditerranéennes et Orientales

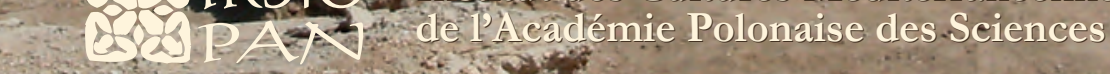

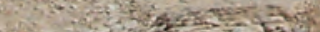

Q 
COMITÉ DE RÉDACTION SCIENTIFIQUE

Maciej Makowski - rédacteur en chef

Jadwiga Iwaszczuk - rédacteur

Katarzyna Kapiec - secrétaire de la rédaction

Henryk Meyza - rédacteur thématique du volume

CONSEIL SCIENTIFIQUE DU JOURNAL

M. Kobusiewicz (IAE PAN, Warszawa)

E. Laskowska-Kusztal (IMOC PAS, Warszawa)

D. Michaelides (University of Cyprus, Nicosia)

J.Ch. Moretti (IRAA-MOM, Université de Lyon 2/CNRS)

D. Raue (Ägyptisches Museum der Universität Leipzig)

P. Reynolds (ICREA, España)

D. Welsby (British Museum, London)

COMITÉ SCIENTIFIQUE DE LECTURE

la liste des membres du comité est accessible en ligne sur

http://www.etudesettravaux.iksiopan.pl

RÉDACTION TECHNIQUE

Marta Kaczanowicz

REVUE DES TEXTES EN ANGLAIS

Jo Harper 
ÉTUDES et TRAVAUX XXXIV 
INSTYTUT KULTUR ŚRÓDZIEMNOMORSKICH I ORIENTALNYCH POLSKIEJ AKADEMII NAUK

\title{
STUDIA i PRACE
}

\section{XXXIV}

\author{
GoIKSiO \\ QSO PAN \\ WARSZAWA \\ 2021
}


INSTITUT DES CULTURES MÉDITERRANÉENNES ET ORIENTALES DE L’ACADÉMIE POLONAISE DES SCIENCES

\section{ÉTUDES et TRAVAUX}

XXXIV

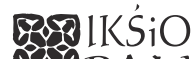

EOSPAN

VARSOVIE

2021 
Publication scientifique financée dans le cadre du programme du Ministre de la Science et de l’Éducation Supérieure

« Programme National de Développement de l’Humanistique » pour les années 2016-2021 (projet no 3bH 150099 83)

\title{
(1) NARODOWY PROGRAM ROZWOJU HUMANISTYKI
}

\author{
Copyright $(C)$ \\ Instytut Kultur Śródziemnomorskich i Orientalnych PAN \\ et les Auteurs \\ Warszawa 2021
}

ISSN 2084-6762

(jusqu'en 2011 : 0079-3566)

e-ISSN 2449-9579
Version première en papier, imprimée en Pologne - 150 copies
Version électronique accessible sur
http://www.etudesettravaux.iksiopan.pl

Édition: Polskie Towarzystwo Historyczne et Wydawnictwo Neriton, Warszawa

Conception générale de la couverture : J. Iwaszczuk

Photographie de couverture : Phot. A. Brzozowska-Jawornicka

(Le portique ionique est, péristyle de la Maison « hellénistique », Nea Paphos) 


\section{Table des matières}

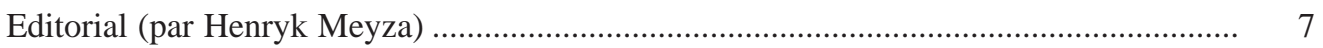

Marta BaJTLER

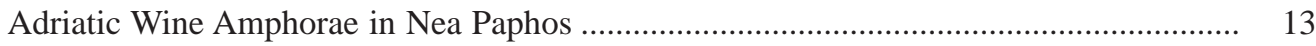

Claire Balandier, Jolanta MlynarczyK

The Temple and Its Surroundings on Fabrika Hill, Paphos: Preliminary Results

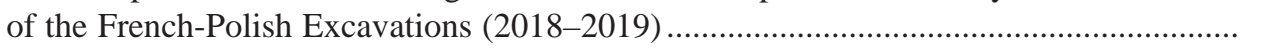

Grażyna BĄKowska-Czerner, Rafal CzERner

The Shell Motif in the Culture and Architecture of the Ancient Town of Marina el-Alamein in Egyp

AleKsandra BrzozowsKa-JaWornicKa

'Hellenistic' House in Nea Paphos, Cyprus - A First Summary of Its Architecture.

AleKsandra BrzozowsKa-JaWORnicKA, AnNa KuBICKA-SowińsKa

In Search of the Module in the Architectural Design of the 'Hellenistic'

House in Nea Paphos, Cyprus

RoKsana HaJduga

Kushite Stamp Impressions from Selib 2, Sudan

ERSIN HusSEIN

Mapping Metal Rich Roman Cyprus: The Case for Object-Centred Approaches

BARBARA LICHOCKA

Villa of Theseus at Nea Paphos (Cyprus). Fourth-Early Fifth Century Numismatic

Evidence for Architectural Transformations and Seismic Events

VASiliki Lysandrou, Demetrios Michaelides

Wall Paintings in Ancient Cyprus: The Hellenistic and Roman Tombs of Paphos

and Its Region

ADAM ŁAJTAR

A Weight of Seleucia in Pieria in Nea Paphos

Diana MroczeK

Ancient Portrait Busts of Marcus Aurelius in the National Museum in Poznań 
Brandon R. Olson, R. Scott Moore, Thomas Landvatter, Justin Stephens

Pyla-Vigla: A Case Study Assessing the Imperial Strategies of the Hellenistic

Diadochoi in Cyprus

Patrizio Pensabene, Eleonora Gasparini

Colonnaded Hall in Kourion: How the Oecus Corinthius Was Interpreted in the Roman

Houses of Cyprus

Monika Rekowska, Demetrios Michaelides, Skevi Christodoulou, JAKUB KANISZEWSKI

Adopting Roman Habits - The Baths in the House of Orpheus in Nea Paphos

as a 'Troublesome' Case Study?

MARCIN M. ROMANIUK

Terracotta Pipelines at Maloutena: Remarks on the Water System in the

Residential District of Ancient Nea Paphos, Cyprus

363

ABRÉVIATIONS

407 